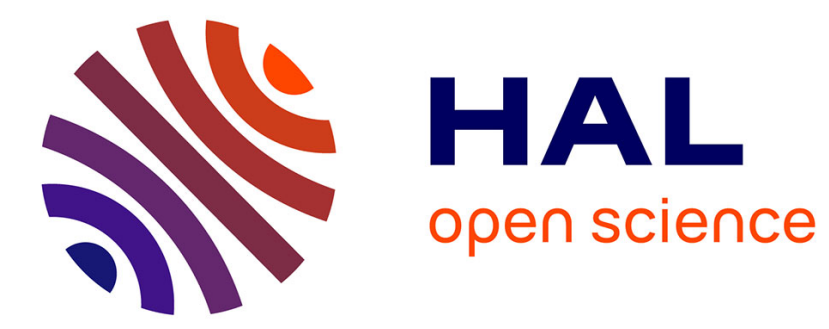

\title{
Struggle over joint audit: on behalf of public interest?
}

Cédric Lesage, Sabine Ratzinger, Jaana Kettunen

\section{To cite this version:}

Cédric Lesage, Sabine Ratzinger, Jaana Kettunen. Struggle over joint audit: on behalf of public interest?. Comptabilités et innovation, May 2012, Grenoble, France. pp.cd-rom. hal-00935004

\section{HAL Id: hal-00935004 https://hal.science/hal-00935004}

Submitted on 22 Jan 2014

HAL is a multi-disciplinary open access archive for the deposit and dissemination of scientific research documents, whether they are published or not. The documents may come from teaching and research institutions in France or abroad, or from public or private research centers.
L'archive ouverte pluridisciplinaire HAL, est destinée au dépôt et à la diffusion de documents scientifiques de niveau recherche, publiés ou non, émanant des établissements d'enseignement et de recherche français ou étrangers, des laboratoires publics ou privés. 


\title{
Struggle over joint audit: on behalf of public interest?
}

\author{
Cédric Lesage* \\ HEC Paris \\ Jouy-en-Josas, France \\ lesage@hec.fr \\ Nicole Ratzinger-Sakel \\ Ulm University \\ Ulm, Germany \\ nicole.ratzinger-sakel@uni-ulm.de
}

Jaana Kettunen

University of Jyväskylä

Jyväskylä, Finland

jaana.m.kettunen@jyu.fi

*: corresponding author

Preliminary draft. No citation permitted. Comments welcome.

This draft $-19^{\mathrm{h}}$ of Mai, 2012

Cédric Lesage acknowledges the financial support of the HEC Foundation (Project F1103) and the INTACCT programme (European Union, Contract No. MRTN-CT-2006-035850). He is member of the GREGHEC, CNRS Unit, UMR 2959. The authors would like to gratefully acknowledge comments on earlier versions of this paper by C. Lennox, D. Stokes and the workshop participants at "Audit market structure, competition and audit quality" conference (KU Leuven, Sept. 2011), EAA (May 2012) and at Bentley University (March 2012) and Concordia University (April 2012) workshops. The authors thank E. Ben Saad for her able help. 


\title{
Struggle over joint audit: on behalf of public interest?
}

\begin{abstract}
European Commission (EC 2011) has recently suggested joint audit - broadly defined as an audit where two independent auditors are jointly liable for the audit report - as a way a way to increase audit quality after the financial crisis and to mitigate audit market concentration, by enlarging the audit offer. Big 4 audit firms have fought this proposal by arguing its unbearable cost while $2^{\text {nd }}$ Tier audit firms have supported it by arguing its added quality. This conflicting position leads us to question their claim of public interest concern. As group-interest economic regulation theories predict that the absence of any effect of a new regulation (here: joint audit) is an evidence of a group rather than a public-interest concern, we test both cost and quality arguments.

We perform our main analysis on Denmark (2002-2010), which gave up the mandatory joint audit in 2005. We test the impact of joint audit on both audit costs proxied by audit fees or total fees and audit quality proxied by abnormal accruals. Our results confirm 1) the nonsignificance association between fees (either audit fees or total fees) and joint audit, and 2) the non-significance association between abnormal accrual and joint audit. We then apply the same approach on a matched French-German sample to assess the arguments based on the French case, as France is characterized by a long tradition of joint audit. We find 1) similar results for audit quality (no significant differences between both countries regarding abnormal accrual in France); and 2) higher fees (audit fees and total fees) in France. However, as given the impossibility to disentangle the effect of joint audit from other institutional differences (as for instance the ban of joint provision of audit and non-audit services in France), we conclude that any argument based on the French case only is dubious. As given the non significance of the hypothesized positive association between joint audit and audit cost or quality, we conclude that arguments raised by both parties relate more to the defense of their private interest than the public (firms or shareholders') interests. The results are of interest for regulators and actors in the audit market.
\end{abstract}

Keywords: joint audit, economic regulation, fees, accruals, audit quality 


\section{Struggle over joint audit: on behalf of public interest?}

\section{Introduction}

Following the Enron scandal and the related Arthur Andersen collapse, various economic actors across the world have feared that a next big audit firm failure will create a dramatic event: "All witnesses fear the real possibility that one of the Big Four might withdraw leaving a Big Three (or even a Big Two, in the bank audit market). We agree. Loss of one of the Big Four would restrict competition and choice to an unacceptable extent." (HoL 2011, § 27). On behalf of public interest protection, the European Commission issued a Green Paper on Auditing (EC 2010) that suggested various institutional mechanisms amongst which joint audit has been one of the most debated suggestions. Joint audit can be broadly defined as an audit where two independent auditors are jointly liable for the audit report. Along with various regulators' initiatives across the world (in the UK ( $\$ 40$, HoL 2011), but also India (Anonymous 2009) and China (Lin et al. 2011)), this proposal is rooted in the following statement (Huber 2011): the big Four audit firms dominate the European listed market, with the noticeable exception of France, where mandatory joint audit has been implemented since 1966.

The European joint audit proposal raised a vivid debate within the accounting profession, and the difficulties in solving it could be illustrated by the decision taken by the EC in November 2011: it finally decided not to make the joint audit mandatory, while at the same time encouraging it (EC 2011a).

The arguments raised by the respective opponents and proponents to joint audit are two-folds. On one side (mostly Big 4 firms), joint audit is said to be costly: "The Committee is not convinced that this would deliver better accounts. It would certainly add bureaucracy and cost." ( $\$ 40$, HoL 2011). On the other side (mostly $2^{\text {nd }}$ tier firms, like Mazars or Grant 
Thorton), joint audit is said to provide higher quality: "There is evidence that concentration is more of a concern than joint audit and I think added quality, value and independence for say a maximum of $5 \%$ additional cost is a way good deal compared to other initiatives." (Cambourg 2011, p. 3, Chairman and CEO of Mazars).

The debate is fierce as the stake is protecting their dominance (for the Big Four) or increasing their market shares (for the $2^{\text {nd }}$ tier firms, like Mazars or Grant Thorton). Consistent with group-interest economic regulation predictions, we question the public interest protection motivations: if the regulation (here: joint audit) is evidenced to have no impact on the market efficiency (here: cost and/or financial statements quality), it would be then suggested that these arguments are mostly discourses whose aim is the group self-interests.

We perform a study on the Danish context as Denmark abolished the joint audit system in 2005. Given the change in regulation, Denmark provides a unique natural field to examine the impact of joint audit within the same institutional setting.

We run audit fee models and abnormal accrual models on 582 Danish firm-year observations (2002-2010). To mitigate the concern of a self-selection bias in Denmark in the post mandatory joint audit period (post 2005) we also perform a two-stage regression with a joint audit selection model as first-stage model. Results evidence 1) a non-significant association between audit fees or total fees and joint audit; 2) a non-significant association between abnormal accruals and joint audit.

As a robustness test, we perform a study on the France case. Given that joint audits are only enforced in France, arguments pro or against joint audit are currently based on the French case. Empirical evidence on the French case is lacking as the effect of the mandatory joint audit cannot be disentangled from the consolidated financial statements disclosure decision ${ }^{1}$.

\footnotetext{
${ }^{1}$ In France, joint audit is mandatory for firms disclosing consolidated financial statements.
} 
Thus, we use a match French-German sample approach and thereby attempt to address the accounting profession's calls for "research on experience in France" (EC 2011, p. 26),

We find 1) similar results for audit quality (no significant differences between both countries regarding abnormal accruals); and 2) higher fees (audit fees and total fees) in France. However, as given the impossibility to disentangle the effect of joint audit from other institutional differences (as for instance the ban of joint provision of audit and non-audit services in France), we conclude that any argument based on the French case only is dubious.

As given the non significance of the hypothesized positive association between joint audit and audit cost or quality, we conclude that arguments raised by both parties relate more to the defense of their private interest than the public (firms or shareholders') interests.

Our paper contributes to prior research as to our best knowledge no prior research on joint audit has ever investigated the joint perspective of audit costs and audit quality on various institutional settings ${ }^{2}$. The examination of various settings (voluntary and mandatory joint audit) allows us to increase the external validity of previous results. We therefore participate to the current vivid debate about the joint audit by providing empirical evidence about its (absence of) efficiency from both cost and quality perspective.

The remainder of the paper is organized as follow. A first section presents the European Commission suggestion and the theoretical basis of our research question grounded on the economic regulation theories. Section 2 develops the paper's hypotheses. Section 3 explains our research design and section 4 details the sampling processing and descriptive results. Section 5 reports the regression results while section 6 presents the additional analyses. Finally, we summarize and conclude the paper, with an acknowledgement of limitations. We also add an Appendix presenting the institutional contexts of auditing in Denmark, France and Germany.

\footnotetext{
${ }^{2}$ Current working papers focus only on one country (Denmark) (Holm and Thinggaard 2011) or on voluntary
} joint audit (Haapamäki et al. 2011). 


\section{Joint audit regulation at the EU level: A public or group interest economic regulation?}

Two main theories of economic regulation have been proposed to explain the pattern of government intervention in the market: "public interest" and "group interest" theories. In this section, we present both theories and their application to the joint audit policy change suggested by the EC.

\subsection{Demand for joint audit as a public interest concern}

The public interest theories of regulation hold that regulation is supplied in response to the demand of the public for the correction of market failures caused by inefficient or inequitable market practices (Pigou 1932). Hence the government intervenes in the market in order to protect public interest with the intent of maximizing social welfare on behalf of society as a whole. Market failures include for instance monopolies, as in this case competition does not exist, which prevents the market from being efficient (Baldwin and Cave 1999).

It appears that the EC followed this pattern when it launched on October 13, 2010 a Green Paper titled "Audit Policy: Lessons from the Crisis“ (EC 2010). While measures adopted both in Europe and elsewhere in the direct aftermath of the financial crisis focus primarily on the stabilization of the financial system and in this context on the role of banks, hedge funds, rating agencies, supervisors or central banks, the Green Paper is an attempt to address more specifically the role of the auditor and its societal mandate. Concerned with the high concentration of the audit market, the European Commission suggested various regulatory changes, amongst which the introduction of joint audits.

Joint audit can be defined as an audit where two independent auditors are jointly liable for the audit report. It may involve a balanced share amount of work (as required by the French law) or not (as permitted by the former Danish law), but in no case it means a systematic double work. More specifically, both teams first agree on each auditor's tasks allocation, and a cross- 
checking procedure enables each audit team to check the other's conclusions and works by reviewing their working files. For the most sensitive issues, both teams can work together. Any disagreeement between both auditors is supposed to be solved before issuing the audit report. Once the audit report is issued, both auditors are jointly held liable for the accuracy of their opinion.

The EC proposal consisted in requiring joint audit with at least one smaller audit firm (e.g., not a Big Four audit firm) for the audits of large companies (EC 2010, p. 16). EC argument is based on evidence that audit market concentration in France where joint audit is mandatory (Big Four market share 2010 for companies with FTSE 350 equivalent market cap: $58 \%$ ) is lower than for instance in Germany that has a long tradition of single audit (Big Four market share 2010 for companies with FTSE 350 equivalent market cap: $82 \%$ ) (Huber 2011).

Following this description, EC proposal seems to have followed the public interest economic regulation prediction: after having identified a market failure, it suggests a policy change to better protect the public interest. In the following we study the various stakeholders reactions within the economic group interest regulation theory.

\subsection{Economic group interest theory and audit firms reactions}

\subsubsection{Economic group interest theory}

The public interest regulation theory has been criticized as it failed to explain the absence of welfare increase after some new economic policy adoption. For instance Stigler and Friedland (1962) evidenced the absence of regulation influence on electricity prices in the United States over the period 1917-1932, which can only be explained by the hypothesis that regulations' objective is not to optimize social welfare, but rather to work in the interest of producers (Deegan, 2009). Hence Stigler formalized a new economic regulation theory in his seminal paper, whose main idea is as follows: “... as a rule, regulation is acquired by the industry and 
is designed and operated primarily for its benefits." (Stigler 1971, p. 3). Later on, Stigler's theory has been refined to include more group interests than a monolithic "industry" group (e.g. Posner (1971, 1974, 1975), and Becker (1983)). As a consequence, the economic group interest regulation theories can be defined on the ground assumption that regulation is supplied as a result of interest groups demands endeavoring among themselves to maximize the incomes of their members (Deegan, 2009). This theory then assumed that individuals form groups to protect certain economic interest. Those groups may have conflicting ideas and interests: hence these groups will lobby the government to put in place legislation that will benefit them economically (Deegan, 2009, p. 135). Thus, private interests are considered to dominate the legislative process, in which the regulatory outcomes will reflect the power equilibrium between all interested parties (Becker 1983). Of course, private interests defense cannot be openly claimed: discourse still remains focused on economic efficiency that appears as the main driver for institutional dynamics: adoption of new institutional mechanisms should be based on its proven higher efficiency, i.e. a greater reduction of transaction costs and information imperfection (North 1990).

We now apply the economic group interest theory to the various stakeholders' reactions to the EC proposal.

\subsubsection{Stakeholders' reactions to EC proposal}

The consultation on the Green Paper closed on December 8, 2010. The European Commission received in total 688 responses, thereof $87 \%$ from EU member states. The majority of comments on the Green Paper came from the audit profession with 59 \%, $21 \%$ came from preparers, and the remaining comments came from other groups like public authorities, users, audit committees, and individuals (IFAC 2011, p. 2). The diversity of arguments raised by the 
proponents and the opponents of joint audit illustrated the fierce debate that followed the EC proposal.

The accounting profession's comments on the joint audit are mixed. The Big Four are against the introduction of joint audits primary due to an alleged impairment of audit quality and coordination problems. In constrast, the mid tier firms and the small and medium sized practitioners (SMPs) are proponents of joint audit. They emphasize the lower concentration in France where the joint audit is mandatory for specific companies (see $§ 3.2$ ) (last paragraph see EC 2011, p. 26). In addition, it is argued by mid tier firms and SMPs that the main benefit of joint audits "is that more firms are able to directly demonstrate high quality in a range of services to a wider range of companies which in turn bolsters the firms' credibility" (EC 2011, p. 27). In their pro joint audit argumentation they also refer to the Danish audit market where - regardless of the abandonment of the mandatory joint audit in 2005 - 16 of Denmark's 64 largest public firms still use the option of joint audits (EC 2011, p. 27).

The majority of investors are against joint audit because of a rise in audit costs, the weaker responsibility or the lack of benefits (EC 2011, p. 27). However some other investor representatives do "not fear the use of audit firm consortiums [joint audits] on a formal basis, provided that the company audit committees properly own the relationships and offer appropriate and effective challenge to the auditors such that the firms in the consortium [joint audit] each deliver a quality audit and challenge each other to improve their approach" (EC 2011, p. 27).

Turning to the public authorities they ask for both clear lines in terms of "the responsibility for the joint audit opinion" and for "a resolution mechasim for differences in opinion" between joint audit members - assumed joint audits were introduced in the EU (EC 2011, p. 27). The Committee of European Securities Regulators (CESR) and the Committee of European Insurance and Occupational Pensions Supervisors (CEIOPS) do not support the 
view that joint audits are a measure to enhance audit market structure (last paragraph see EC 2011, p. 27).

The academics support the view of the introduction of a voluntary joint audit (EC 2011, p. 27). However, they assess a mandatory joint audit as "excessive" (EC 2011, p. 27).

Finally, the preparers, businesses and organisations of companies are not again joint audits given that it is "well balanced, well-framed and with very strict requirements" (EC 2011, p. 27). In this context they stress that the French joint audit model enhances audit quality and it works well because it is well-balenced and profitable. However, the majority believes that the benefits of joint audits (e.g., collusion with management might be more difficult) do not outweight its cons (e.g., increase of audit costs) (last paragraph see EC 2011, p. 27).

Overall most of the comments adressed by the stakeholders' about the EC joint audit proposal are based on an efficiency argument, as predicted by the public interest regulation theory. The main argument stressed against joint audit is the increase of audit costs, while the main argument on the proponents' side is the increase in audit quality. However, it is worthwhile to notice that each position is defended by two distinct groups within the audit industry: Big4 firms and second-tier firms (like Mazars, Grant Thorton, etc.). When expressed in terms of group interest theory, both groups have conflicting goals: the Big4 (resp. 2 tier) group has a rationale interest to discourage (resp. encourage) any economic policy measure that decreases (resp. increases) the audit market competition within EU, which is the primary objective of the EC, as discussed in previous section.

Hence, our question stands as follows: do we actually observe an increase of cost and/or quality in a joint audit case? In case of a positive answer, one (or both ${ }^{3}$ ) group(s) legitimaly act on behalf of general interest. In case of a negative answer, the arguments raised by one (or

\footnotetext{
${ }^{3}$ It should be noted that any combination of both arguments is potentially possible: 1) both arguments could be simultaneously true, as an increase of quality could be associated with an increase in cost; 2) only one can be true ; and 3) none can be true.
} 
both) group(s) deal with group interest protection: using an efficiency argument would appear as a discourse only used to legitimate self-interest actions.

\section{Hypotheses development}

\subsection{Cost hypotheses}

As given the absence of published work about the theory behind the impact of joint audit, we interviewed audit partners to get inside information. On the supply side, one may expect additional costs due to the unavoidable coordination costs: double work at the preliminary phase, double presence to meetings, cross-reviewing of auditors files, etc...An inside study made by one French audit firm concludes to an average over cost of $3 \%$ due to the additional work. Additional premium may also be asked by each auditor to cover the other auditor's risks as they are both jointly liable. Conversely, from the demand side, a joint audit also creates a higher competition between both auditors that can benefit the audited firm. For instance, as two mandates instead of one must be renewed, the client may be able to exert more negotiation power on fees than in a single audit context.

Empirical results are scarce. In the Danish context, Thinggaard and Kiertzner (2008) evidence a negative association between the "de facto" 4 mandatory joint audit and audit fees in year 2002. This result is confirmed by Ittonen and Peni (2011) who show that the voluntary joint audit is associated with lower audit fees in Denmark, Finland and Sweden on the years 20052006. However, André et al. (2011) find an audit fee premium in France compared to the UK, although the authors point out the significantly lower non-audit fees in France than in the UK. Furthermore, the audit-firm pair choice has been associated with audit fees in France under the mandatory joint audit: companies that are audited by two Big4 firms have lower audit fees in comparison to those paid in other cases; the companies with one Big4 and one non-Big4

\footnotetext{
4 "De facto" joint audit means a balanced audit fees allocation between both auditors. Thinggaard and Kiertzner (2008) use total fees to assess the balanced allocation (they test 80-20\% and 60-40\% thresholds).
} 
auditor have the highest audit fees (Gonthier-Besacier and Schatt 2007). However the distribution of audit fees between the auditors (de facto joint audit) does not seem to affect the level of audit fees in France, which is in contrast to the findings from Denmark (GonthierBesacier and Schatt 2007; Thinggaard and Kietzner 2008).

Finally, based on the supply side argumentation (which also corresponds to the joint audit opponents arguments), we expect to find a positive association between audit costs that we proxy by audit fees and the joint audit.

H1: There is a positive association between audit fees and the joint audit.

\subsection{Quality hypothesis}

One and maybe the most popular definition of audit quality was stated by DeAngelo (1981) "Audit quality is defined to be the market-assessed joint probability that a given auditor will both (a) discover a breach in the accounting system and (b) report the breach". This definition consists of two components; hereby the former addresses the auditor's competence and the latter addresses auditor's independence. The joint audit may have a positive effect on either component of audit quality. Assumed that both audit firms involved in the joint audit do not rotate simultaneously, the acquired expertise of one involved audit firm regarding the specific client and its business can be preserved resulting in enhanced auditor competence. While acknowledging the differences, some similarities could be found with the second partner review mechanism. One of the main arguments stated pro second partner reviews has been a positive impact on audit quality and auditor independence (Treadway Commission 1987; (SEC 2010). The positive impact on auditor independence due to second partner review can in its outlines - also be attributed to the joint audit setting. However, in the joint audit system the likelihood of economic bonding that may result in an impairment of auditor independence appears to be less significant than in the single audit system. 
While the above given arguments are stated for the supply side, audit quality in the context of joint audit can also be regarded from the demand side. Client's intention to appoint two different audit firms in a (voluntary) joint audit setting may be explained by signaling a higher level of audit quality to the market. Indeed, there are statements of client firms supporting this assumption by arguing along these lines: "In order to ensure a high degree of assurance for the independence and high quality of auditing, the company's and the group's annual report are audited by two of each other independent state authorized public accountants" (A.P. Moeller Marsk, Annual report 2006, p. 38). The fact that the 16 of Denmark's 64 largest public companies still use the joint audit voluntarily (EC 2011b, p. 27) also leads support to the view that voluntarily appointing two auditors signals a higher level of audit quality to the market.

While thus far we highlighted only arguments supporting an increase in audit quality due to the joint audit, there are also at least some contrary arguments that imply a negative or an insignificant relationship between audit quality and the joint audit. One problem that may arise in the joint audit setting is the 'free-rider problem' mainly known from the economic literature in the context with public goods (Hardin 1968; Olson 1968; Oliver and Walker 1984). Transferred to the joint audit context the free-rider problem can be seen as an attempt of one of the two audit firms to elude its responsibility and relying on the other audit firm's effort. Another problem that may arise in the joint audit setting stressed by audit partners is insufficient information exchange resulting from suboptimal collaboration of the two competing audit firms.

Previous research on the effects of the joint audit on audit quality - proxied by abnormal accruals - is scarce and the empirical findings of these studies are mixed (Gonthier-Besacier and Schatt 2007).

The association between audit firm-pair choice (two Big Four, one Big Four paired with nonBig Four or/vs. two non-Big Four) and abnormal accruals has been examined only in the 
institutional context of France. Francis et al. (2009) find an association between accruals and audit firm-pair choices when abnormal accruals are partitioned into firms with incomeincreasing (positive) versus income-decreasing (negative) abnormal accruals. A Big Four-Big Four pair constrains income-increasing abnormal accruals relative to all other firm combinations (including those using just one Big Four auditor paired with a non-Big Four auditor). However, the choice of audit firm-pair is not associated with income-decreasing abnormal accruals (Francis et al. 2009).

Hence, based on the discussion above we conclude that the theoretical arguments supporting an increased audit quality due to the joint audit exceed the arguments not supporting an increased quality due to the joint audit. This leads to our second hypothesis.

$\mathrm{H} 2$ : There is a positive association between audit quality and the joint audit.

\section{Research design}

Our research design comprises three models: single audit choice model, fees model and abnormal accruals model.

\subsection{Selection model}

As Danish firms can choose the single audit from year 2005, we use a selection model for the post 2005 period. As given the absence, to our best knowledge, of any prior research on the choice of joint-audit ${ }^{5}$, we reference to the arguments stated of the various stakeholders. First opponents claim that joint audit is associates to higher costs, which leads us to assume that a firm with a lagged loss will be more likely to switch to a single audit. Second, the analysis of the response to the EC Green paper (EC 2011) and the comments in newspapers strongly suggest that the Big 4 have been playing against the adoption of joint audit. Hence,

\footnotetext{
${ }^{5}$ We also investigated the determinants of the choice of a Big 4, as given the similarities of the arguments: higher costs and higher quality. However, none of the usual factors referenced in prior literature (Behn et al. 2008, Boone et al. 2008, Clathworthy et al. 2009, Lennox et al. forthcoming) has been found significant.
} 
we assume that the presence of a Big 4 as auditor in the year before the change increases the likelihood of switching to single audit. Lastly, we assume that a firm with a greater market exposure will prefer to keep joint audit, in accordance to audit quality literature (Boone et al. 2008).

Prob $(\mathrm{JOINT})=\alpha_{0}+\alpha_{1}$ LAG_LOSS $+\alpha_{2}$ BIG_0 $+\alpha_{3}$ BIG_1 $+\alpha_{4}$ BIG_2 $+\alpha_{4}$ LAG_PER $+\varepsilon$

Where JOINT equals 1 when the firm is audited by at least two auditors, 0 otherwise, LAG_LOSS equals 1 in case of a loss during prior year, 0 otherwise, BIG 0, 1, 2 equals 1 when there is 0,1 or 2 Big 4 in the prior year, and LAG_PER is the prior year Price-Earnings Ratio.

\subsection{Auditfees model}

We use the following general regression model (2) to test our hypothesis H1:

$\mathrm{FEE}=\beta_{0}+\beta_{1} \mathrm{JOINT}_{-} \mathrm{HAT}+{ }_{k=1}^{13}{ }_{k}$ FEECONTROL $_{k}+$ Fixed effects $+\varepsilon$

Where FEE is defined by the natural logarithm of fees in $K €$, either audit fees or total fees, and FEECONTROL denotes firm-specific variables. All variables are defined in Table 1.

$$
\text { **** Insert Table } 1 \text { here } * * *
$$

In addition to the audit fees, we also proxy FEE by total fees: total costs represented by the auditors are not restrained to audit costs only, as audit firms may also provide non-audit services. Prior research reports mixed evidence on the relationship between audit and nonaudit fees. On the one hand, prior work argues that the relationship between audit and nonaudit fees should be negative (O'Keefe et al. (1994)). Economies of scope may come from a wide range of reasons. First, Simunic (1984) and Hay et al. (2006a) argue that knowledge spillovers between the two types of services can lead to cost savings. Second, it could also be argued that auditing is a "loss leader" (Hillison and Kennelley 1988; Hay et al. 2006a): audit 
services are considered to be the way of having a "foot in the door", which enables them to sell non-audit services. On the other hand, some prior studies suggest that the relationship between audit and non-audit fees is positive. For instance Simunic (1984) shows that both types of services may be driven by similar client characteristics such as client size or client risk. It could also be argued that supplying audit services might enable the audit firm to better identify consulting opportunities for itself (Antle et al. 2006). Using single equation specification of audit fee models, some studies actually evidenced either a positive association between audit and non audit fees (e.g.: Firth 1997) or found no relationship (e.g.: AbdelKhalik 1990). Whisenant et al. (2003) suggested that audit and non audit services could be jointly determined, as also empirically evidenced by Hay et al. (2006a) and Antle et al. (2006).

These arguments strongly advocates for considering total fees instead of audit fees only, as given the complex relationships between both components of audit firms' revenues ${ }^{6}$.This approach would also be consistent with published international studies using fees provided by Worldscope (e.g.: Choi et al. 2009), as Worldscope discloses total fees only.

\footnotetext{
${ }^{6}$ In addition to these theoretical arguments, there is also anecdotal evidence exhibiting inconsistencies of audit/non-audit fee categorization detected across countries but also across firms within the same country. First, one audit partner told us that some audit-related tasks could be considered as audit or non audit services, depending on the country regulation. For instance, SOX related works are generally included into audit services in France, and generally into non-audit services in Germany. Second, concerns about the audit vs. non-audit categorization have been raised within some countries. For instance AMF (the French stock-market regulator) requires fees paid to the statutory auditors to be categorized into 3 Categories: "Audit Fees", "DDL" ("diligences directement liées": Directly Related Assurance services) and "Other Non Audit services". However, it constantly points out the opacity of the segregation and regrets that its recommendation of a precise disclosure about the nature of non-audit fees representing more than $10 \%$ of audit fees is almost never met (AMF 2011). On the same vein, previous studies in Germany (Bigus and Zimmermann 2008; Köhler and Ratzinger forthcoming) have outlined the misclassification issues related to the "vagueness" of the wording of the German commercial code, which gives room for interpretation with respect to the categorization of fees paid to the auditor. As for Denmark, the companies disaggregated the audit fees in years 2002-2007 into two categories (audit, non-audit) but from 2008 into four categories (audit, other assurance services, tax advisory, other advisory). We found examples of non-consistent allocation across companies of the "other assurance services" between audit and nonaudit categories, e.g. Andersen \& Martin has included "Other assurance services" in non-audit fees while ALK Abello considered it as audit fees (sources: Companies Financial Statements 2008-2009. Thus, using total fees appears to be an adequate approach to capture the various concerns of the fee categorization in both across countries and across firms within the same country.
} 
The test variable for H1 is JOINT_HAT, that is the predicted value of a joint audit estimated by the probit selection model for a joint audit (equation (1)). As H1 states a positive association between joint audit and fees, we therefore expect $\beta_{1}$ to be positive.

Our audit fees model includes two types of firm specific control variables, which control for: (1) audit costs (size and complexity); (2) the risk of loss that an audit could face in the future (Simunic 1980; Francis 1984; Hay et al. 2006b). Size is coded by ASSET (natural logarithm of total assets expressed in $\mathrm{k} €$ ). We then add two variables which proxy for client complexity: INVR (sum of the inventories and receivable, scaled by total sales) and BUS (natural log of business segments + 1). Similar to Simunic (1980) and Choi et al. (2009), we include LOSS (negative net income) and LEV (leverage) to measure the client-specific litigation risk potentially borne by the auditors, and we add ROA (Return on Assets), LQD (liquidity ratio), and CROSSLIST to code for being cross-listed in a higher litigation risk market (US or UK) (Choi et al. 2009). We also include the audit firm size (BIG) to capture the Big4 premium (Francis 1984). We also add the year-end peak (PEAK) to capture the busy season effect (Hay et al. 2006b) related to the auditor's peak of activity of the 31st of December. Finally we include an audit demand effect with a Book-to-price ratio (BTP), new issue of capital or longterm debt (NISSUE) and listing on the main market (MINDEX, i.e. C20 Index in Denmark). All coefficients $\delta_{\mathrm{k}}$ are expected to be positive, except for ROA, LQD and BTP. Finally, model (1) includes also fixed year effects and an error term $(\varepsilon)$.

\subsection{Accruals models}

We use the following general regression model (3) to test our Hypothesis H2:

Abnormal accruals $=\lambda_{0}+\lambda_{1}$ JOINT_HAT $+\sum_{k=1}^{7} \pi_{k}$ ACCCONTROL $k+$ Fixed effects $+\mu(3)$

Our dependent variable in model (3) is abnormal accruals, our measure of audit quality. Albeit abnormal accruals are criticized due to their limited predictive accuracy and power to detect 
earnings management, abnormal accruals continue to be used as a measure of earnings quality and therefore to identify differences in audit quality by investigating the accruals properties of audit firm clients (Francis and Wang 2008; Francis et al. 2009). Furthermore the Danish setting does not allow us to use other frequently used proxies of audit quality in Anglo-Saxon settings, i.e., going concern opinions or restatements, since the occurrence of those events is scarce is Denmark and, therefore, the variables would lack the sufficient variance for our analysis.

To give a complete picture we are using four abnormal accruals measures in our analysis for the following reasons: Following Francis and Wang (2008) we use signed abnormal accruals (sig_ABN_ACC) based on Hribar and Nichols (2007) finding that signed abnormal accruals are a better measure of earnings quality than the absolute or unsigned value of accruals. Nonetheless to give a complete picture we also use the absolute value of abnormal accruals (abs_ABN_ACC) as proxy for audit quality based on the rational that an impairment of earnings quality can be due to both overstated and understated earnings. However, based on the argument that the incentives to overstate or to understate earnings may vary (Becker et al. 1998) we furthermore consider the positive value of abnormal accruals (pos_ABN_ACC) and the negative value of abnormal accruals (neg_ABN_ACC) separately in our analysis.

A cross-sectional Jones model (1991) appears to be an inadequate model to calculate abnormal accruals for international data since the number of industry observations per country can be quite small and this may be an explanation why Jones-type abnormal accruals perform unreliable in international settings (Wysocki 2004; Meuwissen et al. 2007; Francis and Wang 2008). Thus, as an approach to face this problem we follow Francis and Wang (2008) and use a linear model adapted from DeFond and Park (2001) to calculate abnormal accruals. We calculate predicted accruals (PRE_ACC) in year t as:

$$
\text { PRED_ACC }_{\mathrm{t}}=\left[\mathrm{SALES}_{\mathrm{t}} *\left(\mathrm{CUR} \_\mathrm{ACC}_{\mathrm{t}-1} / \mathrm{SALES}_{\mathrm{t}-1}\right)\right] / \operatorname{ASSETS}_{\mathrm{t}-1}
$$


Abnormal accruals ( $\mathrm{ABN}$ _ACC) in year $\mathrm{t}$ are defined as the difference between the firm's total accruals (TOT_ACC) in year t and PRED_ACC for year $\mathrm{t}$ (see above):

$$
\mathrm{ABN} \_\mathrm{ACC} \mathrm{t}_{\mathrm{t}}=\mathrm{TOT} \_\mathrm{ACC} \mathrm{t}_{\mathrm{t}}-\mathrm{PRED} \_\mathrm{ACC} \mathrm{t}_{\mathrm{t}}
$$

TOT_ACC in year t are calculated as firm's net income (NET_INCOME) in year $\mathrm{t}$ minus firm's cash flow from operating activities (CFLO) in year t scaled by lagged assets ASSETS $_{\mathrm{t}-}$ 1):

$$
\text { TOT_ACC }=\left[N E T \_I N C O M E_{t}-\text { CFLO }_{t}\right] / \text { ASSETS }_{\mathrm{t}-1}
$$

We get firm's current accruals (CUR_ACC) by taking the sum between TOT_ACC in year t and depreciations and amortizations (DEP_AMO):

$$
\text { CUR_ACC } \mathrm{t}_{\mathrm{t}}=\mathrm{TOT} \_\mathrm{ACC}+\mathrm{DEP} \_\mathrm{AMO} \mathrm{t}_{\mathrm{t}}
$$

The test variable for H2 is JOINT_HAT. Consistent with our fee models JOINT_HAT is the predicted value of a joint audit estimated by the probit selection model for a joint audit (equation (1)). We include a number of firm specific control variables ACCCONTROL that may affect accruals. Similar to Francis and Wang (2008), Willekens and Bruynseels (2009), and Choi et al. (2010), we control for company size (ASSETS), operating cash flow (CFO), leverage (LEV), sales growth rate (GROWTH), growth rate of property plant and equipment (DELTA_PPT), loss in prior year (LAG_LOSS), and Big4 audit engagements (BIG). Finally, model (2) includes also fixed year effects and an error term $(\mu)$. We expect the coefficient on ASSETS, CFO, and BIG to be negative and the coefficients on LEV, GROWTH, DELTA_PPE, and LAG_LOSS to be positive. However, when considering our four abnormal accruals measure, neg_ABN_ACC, we expect the coefficients on LEV, GROWTH, DELTA_PPE, and LAG_LOSS to be negative as firms with a bad liquidity performance, growing firms, and firms exhibiting loss in prior year in general appear to have less incentives to manage income-decreasing abnormal accruals. All variables are defined in Table 1. 


\section{Sample and descriptive statistics}

Both studies (fee models and accruals models) are applied on the Danish sample (year 20022010). Denmark provides a unique setting (see a brief presentation of the Danish auditing context in Appendix 1) to study the impact of the joint audit within the same institutional setting. Our sample is initially composed of all non-financial firms (i.e. all firms with a SICStandard Industrial Classification - different from [SIC] 6000-6999). Table 2 explains the sample selection process.

\section{**** Insert Table 2 here ***}

We exclude firm-year observations with missing values for the control variables. We also drop firms for which we could not hand collect audit fees data. Our final sample includes 582 firm year observations.

\subsection{Single vs. joint audit choice}

Table 3 illustrates the choice made by the firms after the regulation authorized single audit in 2005.

$* * * *$ Insert Table 3 here $* * *$

As showed by Table 3, Panel A, a majority of firms switched in 2005 (44 out of 66 in our sample), and almost (96\%) all of firms have opted for a single auditor by the end of $2010 .^{7}$ We also presents the Big 4 market share, which remains around $86-88 \%$ in our sample, with no apparent impact of the change of regulation in 2005.

Table 3, Panel B presents the probit regression (model 1) of the joint vs. single audit choice. We first notice the strong R2 $(0.178, \mathrm{p}<0.001)$. We then observe that the combination that

\footnotetext{
${ }^{7}$ In its response to the EC Green Paper, Grant Thorton mentioned that 16 out of the 64 Danish largest public firms still preferred joint audit. This proportion has often been cited during the EC debate about joint audit. Despite our inquiries to the EC and professional organizations, we have not been able to get the list of these firms. Our own investigation found that 1) this proportion may refer to a pre 2009 situation (e.g. we have $10 \%$ of firms are joint audited in our 2008 sample); and 2) most of these firms may be banks or insurance companies, or unlisted state-owned companies. Lately, Danish profession has confirmed us that in 2012 almost all large listed companies have switched to a single auditor.
} 
most likely keeps the joint audit is the 2 big 4 auditors in prior year. When marginal effects are computed (not tabulated), we evidence that having a one big 4 in prior year decreases the likelihood of keeping joint audit by $30 \%$ (16\% in case of none big 4). As expected, firms that have experienced a loss in prior year are more likely to switch to a single audit (coeff.: -0.657 , $\mathrm{p}<0.001)$. These results suggest the influence of the Big4 on the client's switching decision, all the more so as no other usual control variables has been found significant (see foot note \#5).

\subsection{Descriptive statistics for fees models}

Table 4 presents descriptive statistics for the dependent and the test variable for the full sample (582 observations, year: 2002-2010) and for the restricted sample (425 observations, year: 2005-2010).

\section{**** Insert Table 4 here ***}

Table 4 Panel A details the fees data. The Danish sample exhibits a mean audit fee of 3.9 MDNK and mean total fees of 7.1 MDNK for the full sample (6.9. MDNK for the restricted sample). Table 4 Panel B provides t-tests statistics of auditors' fees (in percentage of sales) in relation to the joint audit. First, the Danish sample reports a non-significant difference between joint audit (216 (resp. 65) observations for the full (resp. restricted) sample) and single audit (366 (resp. 360) observations for the full (resp. restricted) sample) firms, regardless whether audit fees, non-audit fees or total fees are considered. These results are not consistent with the premises of our hypotheses "H1a: There is a positive association between audit fees and joint audit" and "H1b: There is a positive association between total fees and joint audit". 
Table 4 Panel A also presents descriptive statistics for the control variables. Our full sample exhibits a mean ASSET of 14, a mean leverage (LEV) of $26.5 \%$. It also confirms the high audit market concentration (mean $\mathrm{BIG}=90.2 \%$ ).

Table 5 discloses the correlation matrix of the dependent variable (FEE) and the whole set of independent variables for the full sample.

$* * * *$ Insert Table 5 here $* * *$

This matrix shows that the dependent variables (AUD_FEE and TOT_FEE) are positively and significantly correlated at 0.001 to the joint audit (JOINT). All control variables (LEV excepted) show a significant relationship with the dependent variables. The direction of correlations is mostly consistent with our hypotheses. However, we must run the multivariate analysis before reaching any conclusion on the relations. The magnitudes of the pairwise correlations among firm specific control variables generally do not exceed 0.4 , with the exception of the correlations between ASSET and MINDEX (0.611, p<0.001), LQD and LEV $(-0.412, \mathrm{p}<0.001)$ and LOSS and ROA $(-0.632, \mathrm{p}<0.001)$. We therefore will report the Variance Inflated Factors, as there may be multi-collinearity concerns.

\subsection{Descriptive statistics for Accruals models}

Table 6 Panel A reports descriptive abnormal accruals data.

$$
\text { *** Insert Table } 6 \text { here } * * *
$$

With respect to our first measure of abnormal accruals, sig_ABN_ACC, the Danish sample mean is 0.0056 and the median is -0.0029 when focusing on the entire reporting period 20022010. Limiting the reporting period to 2005-2010 in which Danish companies had the choice to either keep the joint audit or switch to a single audit we find an increase in the average value of sig_ABN_ACC (0.0097) but a decrease in the median (-0.0040). The sample shows a total of $47 \%$ of positive (income-increasing) abnormal accruals and 53\% negative (incomedecreasing) for both the entire period 2002-2010 and the limited period 2005-2010. With 
respect to our second measure of abnormal accruals, abs_ABN_ACC, we again find an increase in the mean when comparing the entire period 2002-2010 (0.0936) and the limited period 2005-2010 (0.1081). Further, we also find an increase in the median when comparing the two periods $\left(\operatorname{median}_{2002-2010}: 0.0405 ; \operatorname{median}_{2005-2010}: 0.0422\right)$. This findings also holds when taking our third measure, pos_ABN_ACC, into account $\left(\operatorname{mean}_{2002-2010}\right.$ : 0.1046; $\left.\operatorname{median}_{2002-2010}: 0.0419 ; \operatorname{mean}_{2005-2010}: 0.1246 ; \operatorname{median}_{2005-2010}: 0.0439\right)$. For our fourth measure, neg_ABN_ACC, we find a decrease in both mean $\left(\right.$ mean $_{2002-2010}:-0.0836$; mean $_{2005-}$ 2010:-0.0921) and median (median $2002-2010:-0.0391$ median $\left._{2005-2010}:-0.0417\right)$ when comparing the periods.

Table 6 Panel B illustrates t-test statistics of abnormal accruals in relation to the joint audit. Independent of the used proxy for audit quality (sig_ABN_ACC, abs_ABN_ACC, pos_ABN_ACC, neg_ABN_ACC), the Danish sample shows a non-significant difference between joint audit and non-joint audit firms in both the entire period 2002-2010 and the limited period 2005-2010. Taken altogether, these findings contradict the premises of our hypothesis "H2: There is a positive association between audit quality and joint audit".

Table 6 Panel A also shows descriptive statistics for the control variables. In the entire period 2002-2010: Danish firms report on average 30.1\% loss in prior financial year (0.301) firms and average operating cash-flow of 0.039; regarding growth, Danish firms exhibits an average of sales growth $17.4 \%$ and $28.0 \%$ for change in PPE. Except for growth we find a decrease in the averages when considering the limited period 2005-2010.

Table 7 reports the correlation matrix of the two of the abnormal accruals measures, sig_ABN_ACC, abs_ABN_ACC and the whole set of independent variables.

$$
\text { *** Insert Table } 7 \text { here } * * *
$$

The matrix indicates that the joint audit (JOINT) is not significantly correlated with both sig_ABN_ACC and abs_ABN_ACC. We find the expected negative relationship for BIG and 
for ASSETS at the $1 \%$ level. Hereby the latter one can only be confirmed by the abs_ABN_ACC while the former one holds for sig_ABN_ACC and abs_ABN_ACC. The expected negative (positive) relationship for CFO (LEV) is only supported by the abs_ABN_ACC. With respect to this finding our results are contradictory when considering the sig_ABN_ACC variable.

The magnitudes of the pairwise correlations among firm specific variables do not exceed 0.3 except between the two abnormal accruals measures sig_ABN_ACC and abs_ABN_ACC, there the positive correlation is 0.706 , which is significant at the $1 \%$ level. However, we do not include both measures in our multivariate setting. Thus, there is no multicollinearity concern in terms of the accruals models. Nonetheless we will report Variance Inflated Factors to be consistent with fee models.

\section{Multivariate regressions results}

All tables presented here report the ordinary least squares (OLS) estimates for the models discussed above. P-values are computed using robust standard errors, adjusted for heteroscedasticity and clustered at the firm level (Petersen 2009). We also include a yeareffect in all regressions ${ }^{8}$.

\subsection{Auditfees models}

Table 8 presents the fees models results for both fees proxies and for two specifications: 1) the restricted sample (year 2005-2010), with the predicted JOINT_HAT variable calculated by the probit regression (eq. 1) ; and 2) the full sample (year 2002-2010), with the collected JOINT variable.

$$
* * * * \text { Insert Table } 8 \text { here } * * *
$$

\footnotetext{
${ }^{8}$ We did not include an industry effect on the Danish sample because of an insufficient number of data per industry segment.
} 
The correlation between AUD_FEE and joint audit, whether we use JOINT_HAT or JOINT, is not significant. When total fees are considered, we also find no association between total fees (TOT_FEE) and joint audit (JOINT or JOINT_HAT). Hence, "H1: There is a positive association between audit fees and joint audit" is not validated.

\subsection{Accruals models}

Table 9 reports multivariate regression results for the accruals models for all four abnormal accruals measures. Panel A shows the result for the period in which Danish firms had the choice to either use a joint or a single audit.

$$
* * * \text { Insert Table } 9 * * *
$$

We do not find the expected negative and significant association for our four measures, sig_ABN_ACC; abs_ABN_ACC, pos_ABN_ACC and neg_ABN_ACC. These findings contradict our Hypothesis 2. Hence "H2: There is a positive association between audit quality and joint audit" is not validated suggesting that there is no audit quality difference between the joint audit and the single audit.

Panel B illustrates the results for the entire period 2002-2010. Consistent with our restricted period 2005-2010 - but contradictory to our Hypothesis 2 - we also find no association between the joint audit and sig_ABN_ACC, abs_ABN_ACC, pos_ABN_ACC and neg_ABN_ACC.

\section{Robustness analysis}

We run two types of robustness analysis. The first one groups additional analyses on the Danish sample. The second one extends the previous research design on a matched FrenchGerman sample. 


\subsection{Alternative proxies and models on the Danish sample}

First, we used alternative proxies for all models, as for instance using sales instead of net assets for size, or coding Big Four as a categorical variable (instead of a dummy). Regarding an alternative proxy for audit quality we were not able to use modified audit opinions because of the low number of those (for instance: 16 out of 449 for which audit-related data were available in Denmark), which in turn results in low variance with respect to this variable. Second, we also use alternative model specifications, as for instance dropping the year effects and including industry effects on the Danish sample. Third, we use a change model for fees and for abnormal accruals, with each firm being its own control match.

In all cases, findings of the main analysis continue to hold.

\subsection{French case: a mandatory adoption context}

We also have decided to investigate the French case, which together with the Danish case, constitutes the source of information for the Big4 and $2^{\text {nd }}$ Tier groups arguments.

As France is characterized by a long tradition of mandatory joint audit (see a brief presentation of the French in the Appendix) and is currently the sole example of a mandatory application of joint audit in Europe, it is very tempting to use this unique context to test the proponents and opponents of the joint audit proposal. The European Commission itself calls for "research on experience in France" (EC 2011, p. 26).

However such a study cannot easily be done. One solution would consist in comparing two French samples (with vs. without joint audit). In that case, one faces the difficulty that joint audit in France is mandatory for any firm disclosing consolidated financial statement, hence making difficult the isolation of the joint audit effect only. An alternative solution consists in building a matched sample with a country with single audit only. Of course, in that case, the difficulty resides in the unavoidable specific insitutional features between both countries. 
As these difficulties do not prevent joint audit proponents and opponents to use the French case, we want to test their claims by adopting the second approach ${ }^{9}$. We then use a matched sample FRA/GER for the following reasons: 1) Germany has always experienced a single audit system with very few voluntary joint audits (see a brief description of the German audit context in Appendix; and 2) both countries are economically closely related and many corporate governance measures are close (see Table 10).

$$
\text { *** Insert Table } 10 * * *
$$

Although we are aware of additional country specific institutional features, a matched FrenchGerman sample hence gives us the best opportunity to test the groups' arguments about a mandatory joint audit system.

\subsubsection{Research design and descriptive statistics}

To match the French companies to the German companies we use a nearest neighbour algorithm ${ }^{10}$ within both two digit SIC code and year, based on the natural logarithm of companies' total assets. Our approach is more conservative than prior matching approaches in order to ensure adequate matching partners. We used the natural logarithm of companies' total assets and we defined a threshold of one, i.e., given that the difference between the natural logarithm of the French and the German companies total assets - that are identified as matches - is greater than one, the matches are classified as non adequate matches.

Table 11 presents descriptive statistics for the audit fee models variables.

$$
\text { **** Insert Table } 11 \text { here *** }
$$

\footnotetext{
${ }^{9}$ This choice is based on the following analysis: it clearly appears from the EC reports that the market concentration concern is focused mostly on the large listed firms. By using the first approach (a within France sample), we will not be able to find a large sample enough of French listed firms that do not report consolidated financial statements.

${ }^{10}$ A propensity score matching requires the so-called conditional treatment probability. In our case the treatment is either Germany or France and a probit or logit model that estimates the probability of being a French or a German company has not been used in prior literature and cannot be modeled easily. Thus, we used the classical matching.
} 
Table 11, Panel A shows a mean audit fees of 2.4 M€ (median: 0.6) for the French sample and the German sample reports a mean audit fees of 1.3 M€ (median: 0.3), which is consistent with previous studies (e.g., 2.2 M€ (median 0.3) for French firms in André et al. (2011) and 0.9 M€ in Köhler and Ratzinger (forthcoming)). The financial variables for the FRA/GER matched sample are very similar. For instance ASSET variable reports a mean (median) of 13.337 (13.234) for the French sample and 13.291 (13.048) for the German sample, or the leverage variable is equivalent (mean: 21.9 for FRA and 23.3 for GER). Those descriptive results support our matching procedure.

Table 11, Panel B reports the comparison between the French and German matched-samples and shows that audit fees (in percentage of sales) are significantly higher $(0.17 \%$ vs. $0.10 \%$, $\mathrm{p}<0.001)$ and non-audit fees (in percentage of sales) are significantly lower $(0.01 \%$ vs. $0.05 \%$, $\mathrm{p}<0.001)$ for the French than for the German firms. When total fees are considered, then no significant difference is found. Then evidence for " $\mathrm{H} 1$ : there is a positive relationship between joint audit and audit fees" is mixed.

Table 12 Panel A reports descriptive accruals data.

*** Insert Table 12 here ***

Regarding the abnormal accruals, in the French sample we find a mean (median) of 0.1551 (0.0531) for sig_ABN_ACC, a mean (median) of 0.1687 (0.0600) for abs_ABN_ACC, a mean (median) of $0.2006(0.0723)$ for pos_ABN_ACC, and a mean (median) of 0.-0.0352 (0.0231) for neg_ABN_ACC. A total of $81 \%$ shows positive abnormal accruals and $19 \%$ has negative abnormal accruals. In terms of the German sample a mean (median) of 0.1375 (0.0520) for sig_ABN_ACC, a mean (median) of 0.1675 (0.0667) for abs_ABN_ACC, a mean (median) of 0.2029 (0.0971) for pos_ABN_ACC, and a mean (median) of -0.0557 (0.0305) for neg_ABN_ACC is reported. The German sample shows a little lower percentage 
of positive abnormal accruals than France with $75 \%$. Accordingly the percentage of negative abnormal accruals is higher with $25 \%$.

Table 12 Panel B illustrates t-test statistics of abnormal accruals in relation to the joint audit. The FRA/GER matched sample confirms our finding of the main analysis, i.e. the absence of a significant difference between joint and non-joint audit firms.

Table 12 Panel A also shows descriptive statistics for the control variables. The financial variables for the FRA/GER matched sample are very similar, especially in terms of ASSET (see also fee models). This finding leads some support to the efficacy of the matching procedure. French firms report on average less loss in prior financial year (0.082) than German firms (0.101). In terms of firm's liquidity we also find on average a higher operating cashflow for French (0.086) than for German firms (0.074). French firms show on average a sale based growth rate of $7.3 \%$ and German firms of $5.6 \%$. Regarding our second proxy for firm's growth we find the following rates for the French firms (mean DELTA_PEE: 0.097) and German firms (mean DELTA_PPE: 0.114). Finally, we find an almost similar Big4 ratio in the French (mean BIG: 0.750) and German sample (mean BIG: 0.726). However, the relative low number of Big Four audit engagements in the German sample appears to be due to the used matched sample approach. In the German audit market for listed companies the Big Four hold a market share of around 90 \% (Köhler and Ratzinger 2010).

\subsubsection{Results}

Table 13 presents fees models results for both fees proxies. **** Insert Table 13 here***

The coefficient between AUD_FEE and JOINT is significant and positive (coeff.: 0.522, $\mathrm{p}<0.001)$. When total fees are considered, results also show a significant and positive 
association between total fees (TOT_FEE) and joint audit (JOINT) (coeff.: 0.209, p<0.01). Finally "H1: There is a positive association between total fees and joint audit" is validated. Table 14 reports multivariate regression results for the accruals models for our four abnormal accruals measures, sig_ABN_ACC, abs_ABN_ACC, pos_ABN_ACC, and neg_ABN_ACC.

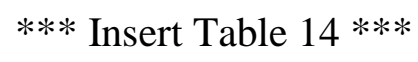

Our findings of the main model can be confirmed for three of our abnormal accruals measures. More specifically, we do not find the predicted negative association between JOINT and sig_ABN_ACC, abs_ABN_ACC, and pos_ABN_ACC. Hence, in line with our main model our findings contradict our Hypothesis 2. Furthermore, with respect to our fourth abnormal accruals measure, neg_ABN_ACC, our matched sample shows a weak (5\%) positive association between joint audit and income-decreasing abnormal accruals. While a positive association suggests an impairment in audit quality - and thus contradicts our Hypothesis 2 - it also gives an indication that the joint audit is related with more conservatism, which is generally preferred by (joint) auditors and risk-adverse investors (Scott, 2011).

\subsubsection{Alternative proxies and models (not tabulated)}

First, we use the same alternative proxies as for the main analysis on the Danish sample and also alternative model specifications, as for instance dropping industry effects. Results continue to hold.

Second, we further investigated the evidenced cost differences between France and Germany. When splitting our sample according to size (based on the mean of log (Asset)), we obtained a more contrasted view. Smaller firms evidence a weaker cost difference (Coeff. JOINT= $+0.195, \mathrm{p}<0.05)$ for audit fees and no difference for total fees, while larger firms still evidence 
a significant positive coefficient for JOINT (for both audit or total fees). Hence the joint audit additional cost effect seems to be mostly driven by larger firms, although the reasons are not clear.

Third, we acknowledge that joint audit is not the only institutional difference between France and Germany; for instance French auditors are mandated for 6 years. Hence, we try to mitigate this concern by considering an "All countries" model (DNK, FRA, GER, adjusted time period and currency) that includes a country fixed effect. This specification shows no impact of joint audit, whether audit or total fees are investigated.

\section{Conclusion}

In this paper, we study the "public interest protection" claimed by both the proponents and opponents of the joint audit institutional mechanism. We test the joint audit efficiency (cost and quality). The vivid debate raised by the EC proposal about the joint audit as an institutional mechanism to decrease the audit market concentration has led us to investigate whether the claimed drawbacks (higher costs) or advantages (higher quality) actually exist. Overall, our results strongly suggest that these claims are not supported. First, the arguments related to the cost dimension appear to be too much simplistic: the Danish case evidences no higher costs (neither audit or total fees) and the higher cost observed on the audit and total fees in France could not be unambiguously attributed to joint audit. Hence one should be cautious when arguing about the additional cost that companies have to bear in a joint-audit setting. For instance, the additional cost observed on audit fees may be more related to the ban of the joint provision of audit and non audit services in France: the "loss leader" effect (Antle et al. 2006) could be more pronounced in Germany than in France, hence leading to higher audit fees in France compared to Germany. 
Second, we do not observe a higher quality associated with joint audit, neither on the Danish sample (main analysis) nor on the matched FRA/GER sample.

It thus seems that efficiency arguments provided by both Big4 and $2^{\text {nd }}$ tier firms are not clearly evidenced in both European contexts where joint audit exists (France) or existed (Denmark). Following the theoretical development based on the theories of regulation, and along the same line as Stigler and Friedland's (1962) seminal empirical work, we must conclude that both groups' arguments rely more on the defence of their self-interest than on the public interest protection. This study is subject to several caveats. First, we approximate audit-related costs by audit and total fees as the auditor's cost structure is not available. Second, the categorization between audit and non-audit fees needs to be further addressed, although previous studies already noticed the probable transfer between audit and non-audit fees, especially in France (Baker et al. 2001; André et al. 2011). Despite these limits, our study aims at participating to the debate about the audit market concentration. It echoes the FEE concerns (Federation of European Accountants - Fédération des Experts-Comptables Européens (FEE) "FEE notes that audit consortia could have an impact on helping to change the concentration in the audit market, although its impact on audit quality is unclear". ${ }^{11}$ Our study suggests that arguments should not be based on the joint audit efficiency, but should rather focus on the risk borne by the financial system in case of a failure involving one of the remaining Big Four audit firms.

\section{References}

Abdel-Khalik, A. R. (1990) The jointness of audit fees and demand for MAS: A self-selection analysis., Contemporary Accounting Research, 6(2), pp. 295-322.

AMF (2011) Etude relative aux honoraires versés aux commissaires aux c omptes et à leur réseau au titre de la période 2010 par les groupes du CAC 40, de l'eurostoxx 50 et

\footnotetext{
${ }^{11}$ Available at: http://www.fee.be/fileupload/upload/Briefing\%20Paper\%2004\%20Appointment\%20of\%20the\%20Auditor\%201 $\underline{1063062011582130 . p d f}$
} 
d'un échantillon de 42 sociétés des compartiments b et c d'eurolist , Autorité des Marchés Financiers, Paris.

André, P., Broye, G., Pong, C. and Schatt, A. (2011) Audit fees, big four premium and institutional settings: The devil is in the details!, Working Paper.

Anonymous (2009) ICAC proposes major audit changes, India Briefing, 24 July 2009.

Antle, R., Gordon, E., Narayanamoorthy, G. and Zhou, L. (2006) The joint determination of audit fees, non-audit fees, and abnormal accruals, Review of Quantitative Finance \& Accounting, 27(3), pp. 235-266.

Baker, C. R., Mikol, A. and Quick, R. (2001) Regulation of the statutory auditor in the European union: A comparative survey of the United Kingdom, France and Germany, European Accounting Review, 10(4), pp. 763-786.

Bigus, J. and Zimmermann, R.-C. (2008) Non-audit fees, market leaders and concentration in the german audit market: A descriptive analysis, International Journal of Auditing, 12, pp. 159-179.

Bruynseels, L. and Willekens, M. (2009) 'Unexpected' audit fees and financial reporting quality in private companies, Working paper.

Bundestag (2004) Beschlussempfehlung und Bericht des Rechtsausschusses (6. Ausschuss) zu dem Gesetzentwurf der Bundesregierung - Drucksache 15/3419 - Entwurf eines Gesetzes zur Einführung internationaler Rechnungslegungsstandards und zur Sicherung der Qualität der Abschlussprüfung (Bilanzrechtsreformgesetz - BilReG), Deutscher Bundestag 2004. Drucksache 15/4054 vom 27.10.2004. Available at: http://dip.bundestag.de/btd/15/040/1504054.pdf (August 15, 2011).

Cambourg, P. d. (2011) Financial reporting and auditing: A time for change?,

Choi, J.-H., Kim, C. F., Kim, J.-B. and Zang, Y. (2010) Audit office size, audit quality and audit pricing, Auditing: A Journal of Practice and Theory, 29(1), pp. 207-220.

Choi, J.-H., Kim, J.-B., Liu, X. and Simunic, D. A. (2009) Cross-listing audit fee premiums: Theory and evidence, Accounting Review, 84(5), pp. 1429-1463.

DeAngelo, L. E. (1981) Auditor size and audit quality, Journal of Accounting and Economics, 3(3), pp. 183-199.

DeFond, M. L. and Park, C. (2001) The reversal of abnormal accruals and the market valuation of earnings surprises, The Accounting Review, 76(3), pp. 375-404.

Djankov, S., La Porta, R., Lopez-de-Silanes, F. and Shleifer, A. (2008) The law and economics of self-dealing, Journal of Financial Economics, 88(3), pp. 430-465.

EC (2010) Green Paper: Audit policy: Lessons from the crisis, 13th of October 2010, European Commission, Brussels, pp. 1-21.

EC (2011a) Restoring confidence in financial statements: The European commission aims at a higher quality, dynamic and open audit market, 30 November 2011, European Commission, Brussels.

EC (2011b) Summary of responses Green Paper - audit policy: Lessons from the crisis, 4th February 2011, European Commission, Brussels, pp. 1-36.

Firth, M. (1997) The provision of nonaudit services by accounting firms to their audit clients., Contemporary Accounting Research, 14(2), pp. 1-21.

Francis, J. R. (1984) The effect of audit firm size on audit prices : A study of the Australian market, Journal of Accounting and Economics, 6(2), pp. 133-151.

Francis, J. R., Vanstraelen, A. and Richard, C. (2009) Assessing france's joint audit requirement: Are two heads better than one ?, Auditing, 28(2), pp. 35-63.

Francis, J. R. and Wang, D. (2008) The joint effect of investor protection and big 4 audits on earnings quality around the world, Contemporary Accounting Research, 25(1), pp. 157-191. 
Gonthier-Besacier, N. and Schatt, A. (2007) Determinants of audit fees for French quoted firms, Managerial Auditing Journal, 22(2), pp. 139-160.

Haapamäki, E., Järvinen, T., Niemi, L. and Zerni, M. (2011) Do joint audits offer value for the money? Abnormal, accruals, earnings conservatism, and auditor remuneration in a setting of voluntary joint audits, Working Paper.

Hardin, G. (1968) The tragedy of the commons, Science, 162(3859), pp. 1243-1248.

Hay, D., Knechel, R. and Li, V. (2006a) Non-audit services and auditor independence: New zealand evidence., Journal of Business Finance \& Accounting, 33(5/6), pp. 715-734.

Hay, D. C., Knechel, W. R. and Wong, N. (2006b) Audit fees: A meta-analysis of the effect of supply and demand attributes, Contemporary Accounting Research, 23(1), pp. 141191.

Hillison, W. and Kennelley, M. (1988) The economics of nonaudit services . Accounting Horizons, 2(3), pp. 32-40.

HoL (2011) Auditors: Market concentration and their role, March, HL Paper 119-I, House Of Lords Select Committee on Economic Affairs, The Stationery Office Limited, London.

Holm, C. and Thinggaard, F. (2011) Joint audits - benefit or burden?, Working paper.

Holm, C. and Warming-Rasmussen (2007) An account of accountants. Audit regulation and the audit profession in Denmark, in Auditing, trust and governance - regulation in Europe (Eds, Quick, R., et al.).

Hribar, P. and Nichols, D. (2007) The use of unsigned earnings quality measures in tests of earnings management, Journal of Accounting Research, 44(5), pp. 1017-1053.

Huber, N. (2011) The concentration battle, International Accounting Bulletin, pp. 6-11.

IDW (2010) IDW stellungnahme zur rechnungslegung: Anhangangaben nach § $285 \mathrm{nr} .17$ hgb bzw. $\S 314$ abs. $1 \mathrm{nr} .9$ hgb über das abschlussprüferhonorar (IDW rs hfa 36), stand: 11, IDW Fachnachrichten, 6, pp. 245-247.

Ittonen, K. and Peni, E. (2011) Auditor's gender and audit fees, The International Journal of Auditing, forthcoming, pp.

Jones, J. (1991) Earnings management during import relief investigations, Journal of Accounting Research, 29(2), pp. 193-228.

Köhler, A. G. and Ratzinger, N. V. S. (2010) Im blickpunkt: Wp-markt in Deutschland: Abschlussprüferhonorare nach geschäftsberichten von mandantenunternehmen und nach transparenzberichten, BetriebsBerater, 65(40), pp. VI-VII.

Köhler, A. G. and Ratzinger, N. V. S. (forthcoming) Audit and non-audit fees in Germany impact of audit market characteristics, Schmalenbach Business Review, pp.

La Porta, R., Lopez-de-Silanes, F., Shleiffer, A. and Vishny, R. (1998) Law and finance, Journal of Political Economy, 106(6), pp. 1113-1155.

Lin, C.-J., Lin, H.-L. and Yen, A.-R. (2011) Dual audit, audit firm independence, and audit quality: Evidence from China, Working paper.

LSF (2003) Loi n²003-706 du 1 août 2003 de sécurité financière.

Meuwissen, R., Moers, F. and Peek, E. (2007) An evaluation of abnormal accruals measurement in an international context,, Working Paper.

NEP-100 (2011) Arrêté du 10 avril 2007 publié au J.O. n 103 du 03 mai 2007, modifé le 03 août 2011.

North, D. (1990) Institutions, institutional change and economic performance, (Cambridge: Cambridge University Press).

Oliver, K. and Walker, M. (1984) The free rider problem: Experimental evidence, Public Choice, 43(1), pp. 3-24.

Olson, M. (1968) The logic of collective action: Public goods and the theory of groups, (New York: Schocken Books). 
Petersen, M. A. (2009) Estimating standard errors in finance panel data sets: Comparing approaches, Review of Financial Studies, 22(1), pp. 435-480.

Piot, C. and Janin, R. (2007) External auditors, audit committees and earnings management in France, European Accounting Review, 16(2), pp. 429-454.

Quick, R. and Warming-Rasmussen (2005) The impact of MAS on perceived auditor independence - some evidence from Denmark, Accounting Forum, 29, pp. 137-168.

SEC (2010) Public company accounting oversight board; order approving proposed rules on auditing standard no. 7, engagement quality review, and conforming amendment, release no. 34-61363; file no. PCAOB-2009-02, january 15, 2010,

Simunic, D. A. (1980) The pricing of audit services: Theory and evidence, Journal of Accounting Research, 18(1), pp. 161-190.

Simunic, D. A. (1984) Auditing, consulting, and auditor independence., Journal of Accounting Research, 22(2), pp. 679-702.

Thinggaard, F. and Kietzner (2008) Determinants of audit fees: Evidence from a small capital market with a joint audit requirement, International Journal of Auditing, 12(2), pp.

Whisenant, S., Sankaraguruswamy, S. and Raghunandan, K. (2003) Evidence on the joint determination of audit and non-audit fees., Journal of Accounting Research, 41(4), pp. 721-744.

Wingate, M. (1997) An examination of cultural influence on audit environment, Research in Accounting Regulation, 11(Supplement), pp. 129-148.

Wysocki, P. (2004) Discussion of ultimate ownership, income management, and legal and extra-legal institutions, Journal of Accounting Research, 42(2), pp. 463-474.

Zimmermann, R.-C. (2006) Gestaltungsspielräume bei veröffentlichung von abschlussprüferhonoraren im rahmen des bilreg, Zeitschrift für internationale und kapitalmarktorientierte Rechnungslegung, 6, pp. 273-276. 


\section{Appendix: Institutional contexts}

In this appendix, we present the three institutional contexts that are used in our empirical study: Denmark, France and Germany. These countries require listed companies to disclose their consolidated financial statements based on IFRS since 2005 that must be audited by (an) appointed auditor(s). However, some institutional mechanisms regarding auditing still differ.

\section{A. Danish context}

In Denmark, the listed and state-owned companies were required to be audited by two mutually independent auditors from 1930 through 2004. The auditors had a joint liability in the audit but Auditing Act did not specify how the audit work or audit fees had to be shared between the two auditors. As a result, many times one of the audit firms received more than 80 percent of the audit fees (Thinggaard and Kietzner 2008). One of the auditors needed to be a state authorized auditor ( $\mathrm{R} L$ ). In 2001, the Danish parliament adopted the new Financial Statements Act () that decided the abandonment of mandatory joint audit by 2005 , after 75 years due to "unnecessary high audit costs" (Danish Financial Statement Act 2001, Basis for Conclusions § 135). Smallest companies need not be audited (årsregnskabslov, ÅRL §135). The listed companies were first required to disclose the group auditor's fees in the notes to the consolidated financial statements in year 2002 (disaggregation between both audit firms and between audit and non-audit fees). Since 2008, auditor's fees are presented by the four categories (audit, other assurance, tax advisory and other advisory services fees) (ÅRL §96). Regarding auditor's independence, the development of Danish regulation has been in contrast to the international development. Until 2003, the Danish auditors were allowed to provide only few non-audit services, but the current regulation on the provision of non-audit services by the statutory auditor is quite liberal (Quick and Warming-Rasmussen 2005; Thinggaard and Kietzner 2008). During the time frame of the study auditors were allowed to provide to 
the client advisory services that are related to audit or other related field if the auditor has the expertise for these services, and there were only some minor provisions that constrained the non-audit services by the auditor (Thinggaard and Kietzner 2008). As a general restriction, the auditor is not allowed to provide non-audit services if this would lead "to circumstances that may raise doubts about his independence in the eyes of a well-informed third party" (translation of LSRR $§ 11$ by Holm and Warming-Rasmussen (2007, p. 45)).

In Denmark, audit market concentration among the listed companies is one of the lowest in Europe as measured by the market share of the BIG4 companies or Herfindal-Hirschman index (London Economic and Evert 2006, p. 20)

\section{B. French context}

The audit regulation in France is notably marked by the joint audit, which has been created by the law in 1966 for listed companies (Loi du 24 juillet 1966, Art. 223 al. 3). This obligation has been extended in 1984 (Art. L 823-2, Code de commerce), which makes the joint audit mandatory for any firm disclosing consolidated financial statements. Joint audit practices are described in a specific national standard (NEP-100 2011). As joint audit seeks to improve audit quality, and most specifically auditor's independence (Gonthier-Besacier and Schatt 2007), French audit regulation also requires a balanced audit work allocation between both auditors "to ensure an efficient dual control mechanism" (Gonthier-Besacier and Schatt 2007, p. 141). In any case, a cross-reviewing of each other's working papers is required. Both auditors jointly report to the Board committee and to the shareholders. Each of the joint auditors signs the audit report and they are hence jointly liable for any misstatement. They must report in the audit report any disagreement in their opinion. Their audit and non-audit fees are separately disclosed. Each auditor is appointed by the shareholders for six years, which provides them a form of legal protection (Piot and Janin 2007). 
Another characteristic is the prevention of provision of non-audit services by statutory auditors. This strict regulation dates back to 1934 and has been reinforced by the Loi sur la Sécurité Financière regulation (LSF 2003). A statutory auditor cannot for instance provide tax consultancy, or any non-directly-related to its assurance services.

The French audit market is also characterized by a lower concentration than observed in other comparable countries. Joint audit is generally suggested as the main cause for this phenomenon. But another specificity must also be taken into account: a firm must appoint one auditor when it exceeds two of the three following thresholds on two succeeding years: sales $>3.1 \mathrm{M} €$; total assets: $1.55 \mathrm{M} €$; number of employees: 50 . Those low thresholds in comparison to similar countries help the accounting profession to maintain small audit firms.

\section{German context}

Pursuant to the IDW Auditing Standard 208 (Institut der Wirtschaftsprïfer in Deutschland e.V. (IDW), Institute of Public Auditors in Germany, Incorporated Association) a statutory audit can be conducted as a joint audit. In the event that the audit is performed as a joint audit, the responsible auditors of the two involved audit firms are jointly liable for the audit and a single audit report is issued and signed by the auditors of record. However, the number of listed German firms that voluntarily choose two audit firms is very low.

In Germany, audit and non-audit fee information became publicly available only recently, effective January 1, 2005, the German Commercial Code (section 314 paragraph 1 no. 9) requires that listed firms disclose audit and non-audit fees for both the parent company and for subsidiaries across the following four categories: a) audit fees, b) other attestation services, c) tax services and d) other services. Note that since the wording of the German law lacks precise definition criteria, there is room for interpretation with respect to the categorization of fees paid to the auditor (Zimmermann 2006; Bigus and Zimmermann 2008). In case that the 
audit is conducted as voluntary joint audit, fee information for the two involved audit firms have to be disclosed separately per category (IDW 2010, RS HFA 36 no. 16).

The legislator's primary interest of the Accounting Law Reform Act is strengthening auditor's independence (Bundestag 2004, p. 29). Thus beside the disclosure of fee information the Accounting Law Reform Act also bans certain types of non-audit services to audit clients (section 319 German Commercial Code) with stricter rules for listed clients (section 319a German Commercial Code). 
Table 1: Empirical definitions of variables

Panel A: Fee models

\begin{tabular}{|c|c|c|}
\hline Variable & Empirical definition & Data source \\
\hline \multicolumn{3}{|c|}{ Dependent variable and test variables for Firm $\mathrm{i}$ in Country $\mathrm{j}$ in Year $\mathrm{t}$} \\
\hline AUD_FEE $_{i j t}=$ & natural log of audit fee in thousands of Currency units ( $€$ or DNK) & Financial Statements ${ }^{\text {(a) }}$ \\
\hline TOT_FEE $_{i j t}=$ & natural log of total fee in thousands of Currency units ( $€$ or DNK) & Financial Statements ${ }^{(a)}$ \\
\hline $\mathrm{JOINT}_{i j}=$ & 1 if firm $i$ uses at least 2 audit firms, and 0 otherwise & Financial Statements ${ }^{\text {(a) }}$ \\
\hline \multicolumn{3}{|c|}{ Firm-Specific control variables for Firm $\mathrm{i}$ in Country $\mathrm{j}$ in Year $\mathrm{t}$} \\
\hline $\operatorname{ASSET}_{i j t}=$ & natural $\log$ of total assets in thousands of Currency units ( $€$ or DNK) & Worldscope \\
\hline $\mathrm{INVR}_{i j t}=$ & the sum of inventories and receivables divided by total sales & Worldscope \\
\hline BUS $_{i j t}=$ & natural log of (business segments +1 ) & Worldscope \\
\hline $\operatorname{LOSS}_{i i t}=$ & 1 if firm $i$ reports a loss in year $t$, and 0 otherwise & Worldscope \\
\hline $\mathrm{LEV}_{i j t}=$ & the ratio of year-end total debt to total assets & Worldscope \\
\hline $\mathrm{ROA}_{i j t}=$ & Return on Asset & Worldscope \\
\hline $\mathrm{LQD}_{i j t}=$ & the ratio of current assets to current liabilities & Worldscope \\
\hline $\operatorname{PEAK}_{i j t}=$ & 1 if firm $i$ 's fiscal year-end is 31 rst of December & Worldscope \\
\hline $\mathrm{BIG}_{i j t}=$ & 1 if firm $i$ uses one of the big 4 auditors, and 0 otherwise & Financial Statements (a) \\
\hline $\mathrm{XLIST}_{i j t}=$ & 1 if firm $i$ is cross-listed on a UK or US market, and 0 otherwise & Worldscope \\
\hline $\mathrm{BTP}_{i j t}=$ & the ratio of common equity to equity price & Worldscope \\
\hline $\operatorname{ISSUE}_{i j t}=$ & 1 if total shares of outstanding increased by $5 \%$ or total debt increased by $5 \% ; 0$ otherwise. & Worldscope \\
\hline $\operatorname{MINDEX}_{i i t}=$ & 1 if the firm is listed on the main index; 0 otherwise. & Worldscope \\
\hline
\end{tabular}

(a) Audit-related data are hand-collected from the firms' financial statements and audit reports. 
Panel B: Accruals models

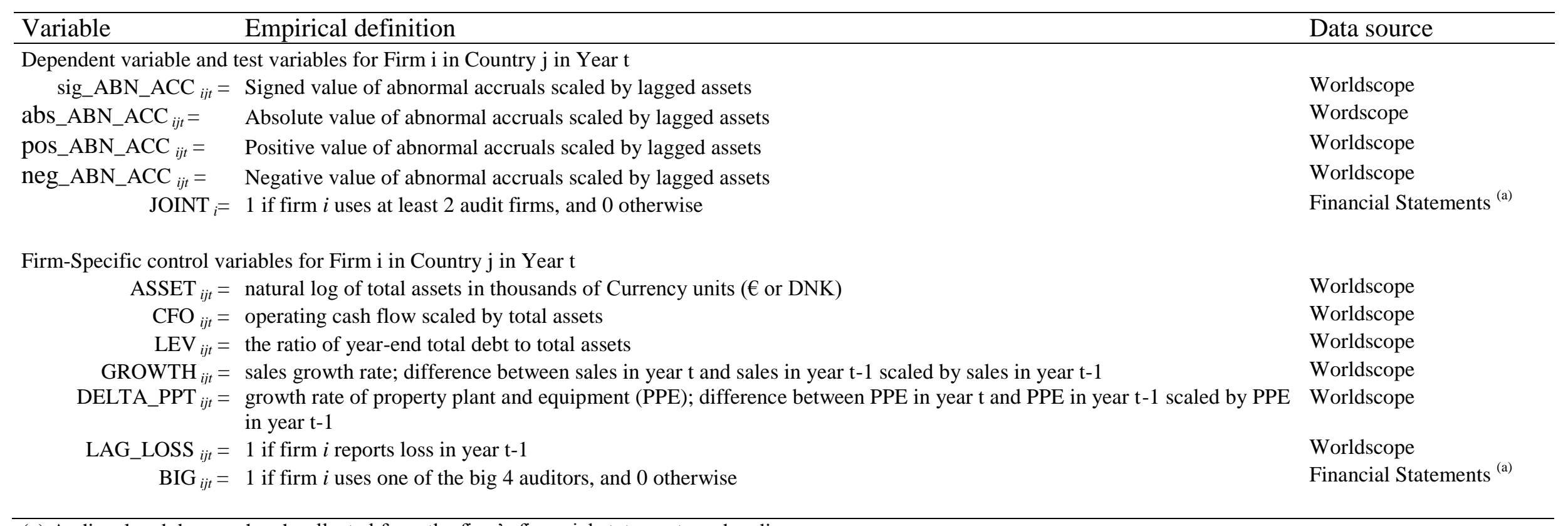

(a) Audit-related data are hand-collected from the firm's financial statements and audit reports. 
Table 2: Sample selection

\begin{tabular}{lr}
\hline Nb. of observations for non financial firms from Worldscope for Denmark (2002-2010) & 1256 \\
less: one-off short fiscal year & -24 \\
less: observation with missing audit-related data & -298 \\
less: missing values on control variables & -352 \\
Total Sample & 582 \\
\hline
\end{tabular}


Table 3: Joint vs. single audit

Panel A: Evolution of Joint vs. Single audits

\begin{tabular}{cccccc}
\hline Year & Single & Joint & Total & $\begin{array}{c}\text { Single audit } \\
\%\end{array}$ & $\begin{array}{c}\text { BIG4 } \\
\text { market } \%\end{array}$ \\
\hline 2002 & 0 & 41 & 41 & $0 \%$ & $85 \%$ \\
2003 & 0 & 48 & 48 & $0 \%$ & $88 \%$ \\
2004 & 0 & 61 & 61 & $0 \%$ & $89 \%$ \\
2005 & 44 & 22 & 66 & $67 \%$ & $85 \%$ \\
2006 & 55 & 15 & 70 & $79 \%$ & $86 \%$ \\
2007 & 58 & 11 & 69 & $84 \%$ & $86 \%$ \\
2008 & 70 & 8 & 78 & $90 \%$ & $85 \%$ \\
2009 & 75 & 7 & 82 & $91 \%$ & $84 \%$ \\
2010 & 64 & 3 & 67 & $96 \%$ & $88 \%$ \\
\hline Total & 366 & 216 & 582 & & $86 \%$ \\
\hline
\end{tabular}

Panel B: Switching decision model

Probit regression

(Error adjusted for 89 clusters (firms))

\begin{tabular}{lllll}
\hline joint & Coef. & Std. Err & $\mathrm{z}$ & p-value \\
\hline Obig4_t_1 & -1.965 & 0.426 & -4.610 & 0.000 \\
1big4_t_1 & -1.190 & 0.255 & -4.660 & 0.000 \\
2big4_t_1 & (omitted) & & & \\
loss_t_1 & -0.657 & 0.194 & -3.390 & 0.001 \\
per_t_1 & -0.001 & 0.000 & -2.250 & 0.024 \\
_cons & 0.122 & 0.189 & 0.640 & 0.519 \\
\hline N & & & 425 & \\
Wald (Chi2(4)) & & 58.040 & \\
P-value & & & 0.000 & \\
Log pseudolikelihood & & -149.452 & \\
R2 & & & 0.178 \\
\hline
\end{tabular}


Table 4: Descriptive statistics Fees and Joint Audit

Panel A: Descriptive statistics

\begin{tabular}{|c|c|c|c|c|c|c|c|c|c|c|c|}
\hline & \multicolumn{7}{|c|}{$\mathrm{N}=582(2002-2010)$} & \multicolumn{4}{|c|}{$\mathrm{N}=425(2005-2010)$} \\
\hline & mean & $\mathrm{sd}$ & $\min$ & $\mathrm{p} 50$ & $\max$ & & mean & sd & $\min$ & $\mathrm{p} 50$ & $\max$ \\
\hline Audit fees (kDNK) & 3888.1 & 6615.1 & 58.5 & 1320.0 & 43000.0 & & 3944.1 & 7006.5 & 58.5 & 1280.0 & 43000.0 \\
\hline AUD_FEE & 7.3 & 1.3 & 4.1 & 7.2 & 10.7 & & 7.3 & 1.3 & 4.1 & 7.2 & 10.7 \\
\hline Non audit fees (kDNK) & 3256.7 & 6623.6 & 0.0 & 850.5 & 63200.0 & & 2967.8 & 5891.1 & 0.0 & 863.0 & 45000.0 \\
\hline Total fees (kDNK) & 7144.8 & 12713.7 & 83.6 & 2158.0 & 88000.0 & & 6911.9 & 12484.3 & 83.6 & 2153.0 & 88000.0 \\
\hline TOT_FEE & 7.9 & 1.3 & 4.4 & 7.7 & $\bullet$ & 11.4 & 7.9 & 1.3 & 4.4 & 7.7 & 11.4 \\
\hline ASSET & 13.984 & 1.825 & 9.860 & 13.805 & 19.463 & & 14.006 & 1.850 & 9.860 & 13.853 & 19.463 \\
\hline INVR & 0.353 & 0.213 & 0.008 & 0.357 & 0.807 & & 0.348 & 0.214 & 0.008 & 0.356 & 0.807 \\
\hline BUS & 1.319 & 0.442 & 0.693 & 1.386 & 2.197 & & 1.315 & 0.445 & 0.693 & 1.386 & 2.197 \\
\hline LEV & 0.265 & 0.200 & 0.000 & 0.250 & 0.824 & & 0.258 & 0.206 & 0.000 & 0.234 & 0.824 \\
\hline ROA & 0.584 & 18.392 & -94.587 & 4.049 & 40.654 & & -0.427 & 19.146 & -94.587 & 3.747 & 40.654 \\
\hline LOSS & 0.320 & 0.467 & 0.000 & 0.000 & 1.000 & & 0.351 & 0.478 & 0.000 & 0.000 & 1.000 \\
\hline LQD & 2.099 & 2.045 & 0.280 & 1.495 & 14.020 & & 2.012 & 1.856 & 0.280 & 1.405 & 14.020 \\
\hline BIG & 0.902 & 0.297 & 0.000 & 1.000 & 1.000 & & 0.875 & 0.331 & 0.000 & 1.000 & 1.000 \\
\hline PEAK & 0.739 & 0.440 & 0.000 & 1.000 & 1.000 & & 0.746 & 0.436 & 0.000 & 1.000 & 1.000 \\
\hline NISSUE & 0.435 & 0.496 & 0.000 & 0.000 & 1.000 & & 0.473 & 0.500 & 0.000 & 0.000 & 1.000 \\
\hline BTP & 0.821 & 0.630 & -0.153 & 0.636 & 2.894 & & 0.792 & 0.640 & -0.153 & 0.586 & 2.894 \\
\hline XLIST & 0.040 & 0.195 & 0.000 & 0.000 & 1.000 & & $\mid 0.038$ & 0.191 & 0.000 & 0.000 & 1.000 \\
\hline MINDEX & 0.131 & 0.337 & 0.000 & 0.000 & 1.000 & & 0.125 & 0.331 & 0.000 & 0.000 & 1.000 \\
\hline
\end{tabular}

With: AUD_FEE $=$ natural log of audit fee $(\mathrm{kDNK})$; TOT_FEE $=$ natural log of total fee $(\mathrm{kDNK})$; ASSET = natural log of total assets $(\mathrm{kDNK})$; INVR = sum of inventories and receivables divided by total sales; BUS $=$ natural log of (business segments +1 ); LOSS $=1$ if the firm reports a loss, and 0 otherwise; LEV $=$ the ratio of year-end total debt to total assets; ROA = Return on Assets, LQD = the ratio of current assets to current liabilities; PEAK = 1 if the firm's fiscal year-end is 31 rst of December, and 0 otherwise; $\mathrm{BIG}=1$ if the firm uses one of the big 4 auditors, and 0 otherwise; XLIST $=1$ if the firm is cross-listed on a UK or US market, and 0 otherwise; BTP $=$ the ratio of common equity to equity price; NISSUE $=1$ if total shares of outstanding increased by $5 \%$ or total debt increased by $5 \%$, and 0 otherwise. MINDEX $=1$ if the firm is listed on the main index, and 0 otherwise. 
Panel B: Fees and joint audit

\begin{tabular}{|c|c|c|c|c|c|c|c|c|c|c|c|}
\hline & & & \multicolumn{3}{|c|}{$\%$ audit fees/sales } & \multicolumn{3}{|c|}{$\%$ non audit fees/sales } & \multicolumn{3}{|c|}{$\%$ total fees/sales } \\
\hline DNK & & $\mathrm{N}$ & mean & $\mathrm{t}$ & $\mathrm{p}$-value & mean & $\mathrm{t}$ & $\mathrm{p}$-value & mean & $\mathrm{t}$ & $\mathrm{p}$-value \\
\hline \multirow[t]{2}{*}{$\mathrm{N}=582(2002-2010)$} & $\begin{array}{l}\text { Joint } \\
\text { Single }\end{array}$ & $\begin{array}{l}216 \\
366\end{array}$ & $\begin{array}{l}0.40 \% \\
0.62 \%\end{array}$ & 1.092 & 0.138 & $\begin{array}{l}0.86 \% \\
1.20 \% \\
\end{array}$ & 0.49 & 0.310 & $\begin{array}{l}1.27 \% \\
1.82 \%\end{array}$ & 0.656 & 0.256 \\
\hline & Total & 582 & $0.54 \%$ & & & $1.08 \%$ & & & $1.62 \%$ & & \\
\hline \multirow[t]{2}{*}{$\mathrm{N}=425(2005-2010)$} & $\begin{array}{l}\text { Joint } \\
\text { Single }\end{array}$ & $\begin{array}{r}65 \\
360 \\
\end{array}$ & $\begin{array}{l}0.35 \% \\
0.63 \%\end{array}$ & 0.888 & 0.187 & $\begin{array}{l}0.89 \% \\
1.22 \% \\
\end{array}$ & 0.283 & 0.389 & $\begin{array}{l}1.24 \% \\
1.85 \% \\
\end{array}$ & 0.43 & 0.331 \\
\hline & Total & 425 & $0.58 \%$ & & & $1.08 \%$ & & & $1.75 \%$ & & \\
\hline
\end{tabular}

$* \mathrm{p}<0.05, * * \mathrm{p}<0.01, * * * \mathrm{p}<0.001$ (bivariate tests). 
Table 5: Correlation matrix Fee Models

\begin{tabular}{|c|c|c|c|c|c|c|c|c|c|c|c|c|c|c|c|}
\hline & (1) & (2) & (3) & (4) & (5) & (6) & $(7)$ & (8) & (9) & $(10)$ & (11) & (12) & (13) & (14) & (16) \\
\hline AUDFEE (1) & 1 & & & & & & & & & & & & & & \\
\hline TOTFEE (2) & $0.963 * * *$ & 1 & & & & & & & & & & & & & \\
\hline JOINT (3) & $0.170 * * *$ & $0.171 * * *$ & 1 & & & & & & & & & & & & \\
\hline ASSET (4) & $0.900 * * *$ & $0.904 * * *$ & $0.125^{* *}$ & 1 & & & & & & & & & & & \\
\hline INVR & $0.166 * * *$ & 0.072 & 0.019 & -0.014 & 1 & & & & & & & & & & \\
\hline BUS & $0.129 * *$ & 0.080 & 0.063 & $0.146 * * *$ & $0.275^{* * *}$ & 1 & & & & & & & & & \\
\hline LEV & 0.071 & 0.062 & 0.066 & $0.106^{*}$ & $0.115^{* *}$ & $0.153^{* * *}$ & 1 & & & & & & & & \\
\hline ROA & $0.337 * * *$ & $0.266^{* * *}$ & $0.151 * * *$ & $0.378 * * *$ & $0.274 * * *$ & $0.196 * * *$ & -0.00679 & 1 & & & & & & & \\
\hline LOSS & $-0.292 * * *$ & $-0.233 * * *$ & $-0.191 * * *$ & $-0.276 * * *-($ & $-0.267 * * *$ & $-0.142 * * *$ & $0.110 * *$ & $-0.632 * * *$ & 1 & & & & & & \\
\hline LQD & $-0.274 * * *$ & $-0.205^{* * *}$ & $0.036-$ & $-0.213 * * *-($ & $-0.242 * * *$ & $-0.292 * * *$ & $-0.412 * * *$ & $-0.202 * * *$ & $0.140 * * *$ & 1 & & & & & \\
\hline BIG & $0.222 * * *$ & $0.253 * * *$ & $0.205^{* * *}$ & $0.224 * * *$ & -0.018 & -0.0541 & -0.019 & 0.0191 & $-0.109 * *$ & 0.0119 & 1 & & & & \\
\hline PEAK & $0.169 * * *$ & $0.189 * * *$ & -0.021 & $0.222 * * *-($ & $-0.161 * * *$ & -0.054 & $0.096^{*}$ & $-0.095^{*}$ & $0.147 * * *$ & 0.0306 & 0.015 & 1 & & & \\
\hline NISSUE (13) & $-0.100 *$ & -0.050 & -0.0423 & $-0.037-($ & $-0.162 * * *$ & -0.079 & $0.001-$ & $-0.145 * * *$ & $0.083 *$ & $0.099 *$ & 0.009 & -0.00729 & 1 & & \\
\hline BTP & $-0.118 * *$ & $-0.160 * * *$ & 0.0431 & -0.080 & 0.077 & $0.148 * * *$ & $0.0873 *$ & -0.051 & $0.143 * * *$ & $-0.0881 *$ & $-0.089 *$ & 0.063 & -0.038 & 1 & \\
\hline XLIST & $0.205 * * *$ & $0.206^{* * *}$ & 0.008 & $0.161 * * *$ & -0.000 & $0.142 * * *-$ & $-0.137 * * *$ & $0.099 *$ & -0.007 & $-0.0244-$ & $-0.111^{*} *$ & $0.121 * *_{-}$ & $-0.089 *$ & -0.069 & 1 \\
\hline MINDEX(16) & $0.645 * * *$ & $0.656 * * *$ & $0.135 * *$ & $0.611 * * *$ & -0.02 & -0.025 & -0.03 & $0.228 * * *$ & $-0.189 * * *$ & $-0.108 * *$ & $0.128 * * 0$ & $0.149 * * *$ & $-0.0107-0$ & $.238 * * * 0.209 * * *$ & 1 \\
\hline
\end{tabular}

$* \mathrm{p}<0.05, * * \mathrm{p}<0.01, * * * \mathrm{p}<0.001$ (bivariate tests)

With: AUD FEE $=$ natural $\log$ of audit fee $(\mathrm{kDNK})$; TOT FEE $=$ natural log of total fee $(\mathrm{kDNK})$; ASSET $=$ natural log of total assets $(\mathrm{kDNK})$; INVR $=$ sum of inventories and receivables divided by total sales; BUS = natural log of (business segments +1 ); LOSS = 1 if the firm reports a loss, and 0 otherwise; LEV = the ratio of year-end total debt to total assets; ROA = Return on Assets, LQD = the ratio of current assets to current liabilities; PEAK = 1 if the firm's fiscal year-end is 31 rst of December, and 0 otherwise; $\mathrm{BIG}=1$ if the firm uses one of the big 4 auditors, and 0 otherwise; XLIST $=1$ if the firm is cross-listed on a UK or US market, and 0 otherwise; BTP $=$ the ratio of common equity to equity price; NISSUE $=1$ if total shares of outstanding increased by $5 \%$ or total debt increased by $5 \%$, and 0 otherwise. MINDEX $=1$ if the firm is listed on the main index, and 0 otherwise. 


\section{Table 6: Descriptive Statistics Accruals and Joint Audit}

Panel A: Accruals: Descriptive statistics

\begin{tabular}{|c|c|c|c|c|c|c|c|c|c|c|}
\hline & \multicolumn{5}{|c|}{$\mathrm{N}=582(2002-2010)$} & & \multicolumn{4}{|c|}{$\mathrm{N}=425(2005-2010)$} \\
\hline & mean & sd & $\min$ & $\mathrm{p} 50$ & $\max$ & mean & sd & $\min$ & p50 & $\max$ \\
\hline sig_ABN_ACC & 0.0056 & 0.4590 & -3.7321 & -0.0029 & 10.0184 & 0.0097 & 0.5334 & -3.7321 & -0.0040 & 10.0184 \\
\hline abs_ABN_ACC & 0.0936 & 0.4493 & 0.0000 & 0.0405 & 10.0184 & 0.1081 & 0.5224 & 0.0003 & 0.0422 & 10.0184 \\
\hline pos_ABN_ACC $(\mathrm{N}=276 / 198)$ & 0.1046 & 0.6051 & 0.0001 & 0.0419 & 10.0184 & 0.1264 & 0.7133 & 0.0004 & 0.0439 & 10.0184 \\
\hline neg_ABN_ACC $(\mathrm{N}=306 / 227)$ & -0.0836 & 0.2331 & -3.7321 & -0.0381 & 0.0000 & -0.0921 & 0.2609 & -3.7321 & -0.0417 & -0.0003 \\
\hline ASSET & 13.984 & 1.825 & 9.860 & 13.805 & 19.463 & 14.006 & 1.850 & 9.860 & 13.853 & 19.463 \\
\hline LOSS_LAG & 0.301 & 0.459 & 0.000 & 0.000 & 1.000 & 0.322 & 0.468 & 0.000 & 0.000 & 1.000 \\
\hline $\mathrm{CFO}$ & 0.039 & 0.231 & -0.716 & 0.072 & 0.359 & 0.026 & 0.248 & -2.802 & 0.064 & 0.549 \\
\hline LEV & 0.265 & 0.200 & 0.000 & 0.250 & 4.475 & 0.258 & 0.206 & 0.000 & 0.234 & 0.824 \\
\hline GROWTH & 0.174 & 1.138 & -1.000 & 0.061 & 23.020 & 0.207 & 1.299 & -1.000 & 0.075 & 23.020 \\
\hline DELTA_PPE & 0.280 & 3.916 & -0.960 & 0.041 & 1.549 & 0.315 & 4.542 & -0.960 & 0.047 & 1.549 \\
\hline BIG & 0.902 & 0.297 & 0.000 & 1.000 & 1.000 & 0.875 & 0.331 & 0.000 & 1.000 & 1.000 \\
\hline
\end{tabular}

With: sig_ABN_ACC $=$ Signed abnormal accruals scaled by lagged assets calculated via linear model adopted from DeFond and Park $(2001)$; abs_ABN_ACC $=$ Absolute abnormal accruals scaled by lagged assets calculated via linear model adopted from DeFond and Park (2001); pos_ABN_ACC $=$ Positive abnormal accruals scaled by lagged assets calculated via linear model adopted from DeFond and Park (2001); neg_ABN_ACC = negative abnormal accruals scaled by lagged assets calculated via linear model adopted from DeFond and Park (2001); ASSET = natural log of total assets in thousands of DNK; LOSS_LAG = 1 if the firm reports a loss in year t-1, and 0 otherwise; $\mathrm{CFO}=$ operating cash flow scaled by total assets; LEV = the ratio of year-end total debt to total assets; GROWTH = sales growth rate; difference between sales in year $t$ and sales in year $\mathrm{t}-1$ scaled by sales in year $\mathrm{t}-1$; DELTA_PPE = growth rate of property plant and equipment (PPE); difference between PPE in year $\mathrm{t}$ and in year $\mathrm{t}$ 1 scaled by PPE in year $\mathrm{t}-1 ; \mathrm{BIG}=1$ if the firm uses one of the big 4 auditors, and 0 otherwise. 
Panel B: Accruals and joint audit

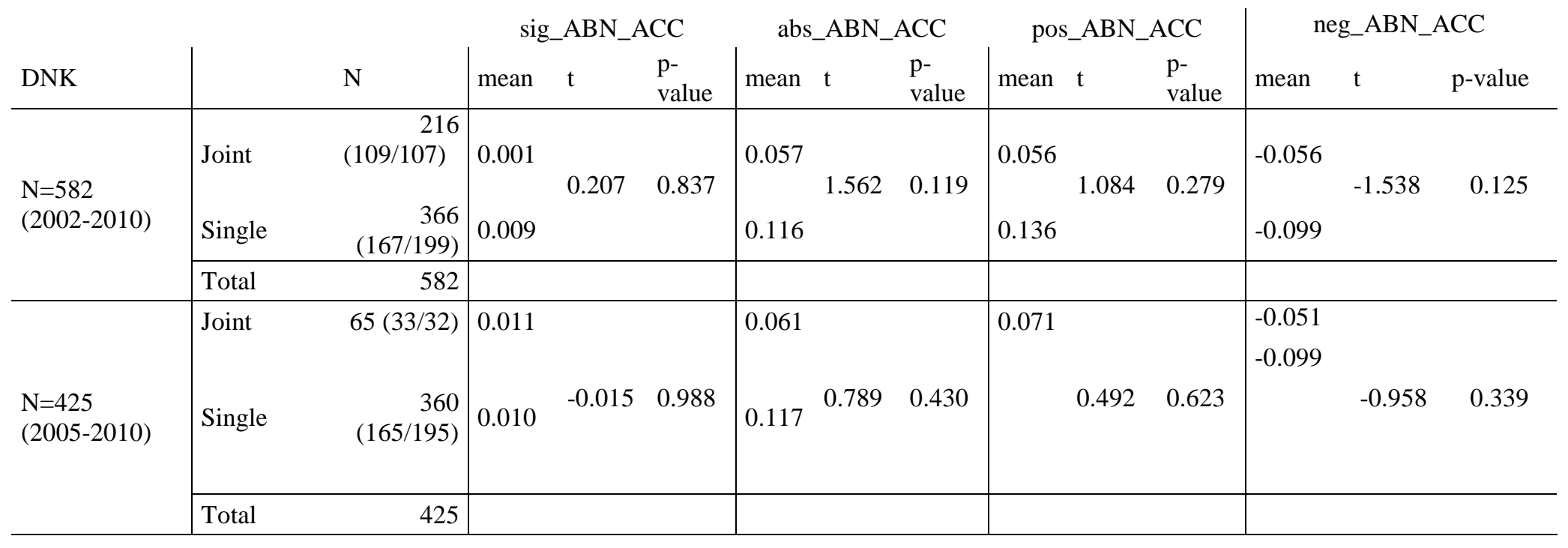

$* \mathrm{p}<0.05, * * \mathrm{p}<0.01, * * * \mathrm{p}<0.001$ (bivariate tests). 
Table 7: Correlation matrix Accrual models

\begin{tabular}{|c|c|c|c|c|c|c|c|c|c|c|}
\hline & sig_ABN_ACC abs_t & ABN_ACC & JOINT & ASSETS & LOSS_LAG & $\mathrm{CFO}$ & LEV & GROWTH DELTA & A_PPE & BIG \\
\hline sig_ABN_ACC & 1 & & & & & & & & & \\
\hline abs_ABN_ACC & $0.706^{* * *}$ & 1 & & & & & & & & \\
\hline ASSET & 0.019 & $-0.133 * * *$ & $0.126 * * *$ & 1 & & & & & & \\
\hline LOSS_LAG & -0.065 & 0.026 & $-0.132 * * *$ & $-0.253 * * *$ & 1 & & & & & \\
\hline GROWTH & -0.009 & 0.031 & -0.062 & -0.026 & $0.122 * * *$ & -0.051 & -0.068 & 1 & & \\
\hline DELTA_PPE & 0.007 & -0.010 & 0.087 & -0.012 & 0.068 & -0.0020 & $.084 * *$ & 0.009 & 1 & \\
\hline $\mathrm{BIG}$ & $-0.133 * * *$ & $-0.118 * * *$ & $0.205^{* * *}$ & $=0.222 * * *$ & -0.061 & -0.017 & -0.006 & -0.054 & 0.011 & 1 \\
\hline
\end{tabular}

$* \mathrm{p}<0.10, * * \mathrm{p}<0.05, * * * \mathrm{p}<0.01$ (bivariate tests)

With: sig_ABN_ACC $=$ Signed abnormal accruals scaled by lagged assets calculated via linear model adopted from DeFond and Park $(2001)$; abs_ABN_ACC $=$ Absolute abnormal accruals scaled by lagged assets calculated via linear model adopted from DeFond and Park (2001); JOINT = 1 if the firm is audited by two auditors, 0 otherwise; ASSET = natural $\log$ of total assets in thousands of DNK; LOSS_LAG $=1$ if the firm reports a loss in year t-1, and 0 otherwise; CFO = operating cash flow scaled by total assets; LEV = the ratio of year-end total debt to total assets; GROWTH = sales growth rate; difference between sales in year $t$ and sales in year t-1 scaled by sales in year t-1; DELTA_PPE = growth rate of property plant and equipment (PPE); difference between PPE in year $t$ and in year $\mathrm{t}-1$ scaled by PPE in year $\mathrm{t}-1 ; \mathrm{BIG}=1$ if the firm uses one of the big 4 auditors, and 0 otherwise. 
Table 8: Fees models regressions

\begin{tabular}{|c|c|c|c|c|c|c|c|c|c|c|c|c|c|}
\hline \multirow{2}{*}{\multicolumn{2}{|c|}{\begin{tabular}{|c|c} 
Expected \\
signs
\end{tabular}}} & \multicolumn{3}{|c|}{ AUD_FEE } & \multicolumn{3}{|c|}{ TOT_FEE } & \multicolumn{3}{|c|}{ AUD_FEE } & \multicolumn{3}{|c|}{ TOT_FEE } \\
\hline & & $\mathrm{b}$ & $\mathrm{p}$ & vif & $\mathrm{b}$ & $\mathrm{p}$ & vif & $\mathrm{b}$ & $\mathrm{p}$ & vif & $\mathrm{b}$ & $\mathrm{p}$ & vif \\
\hline JOINT & + & & & & & & & 0.194 & 0.077 & 2.825 & 0.139 & 0.231 & 2.825 \\
\hline JOINT_HAT & + & 0.061 & 0.398 & 2.020 & 0.010 & 0.88 & 2.020 & & & & & & \\
\hline ASSET & + & $0.598 * * *$ & 0.000 & 2.279 & $0.621 * * *$ & 0.000 & 2.279 & $0.614 * * *$ & 0.000 & 2.169 & $0.639 * * *$ & 0.000 & 2.169 \\
\hline INVR & + & $1.220 * * *$ & 0.000 & 1.317 & $0.849 * * *$ & 0.000 & 1.317 & $1.244 * * *$ & 0.000 & 1.286 & $0.878 * * *$ & 0.000 & 1.286 \\
\hline BUS & + & -0.192 & 0.137 & 1.283 & -0.170 & 0.175 & 1.283 & -0.159 & 0.226 & 1.256 & -0.181 & 0.152 & 1.256 \\
\hline LEV & + & $-0.520 * *$ & 0.01 & 1.397 & $-0.444^{*}$ & 0.017 & 1.397 & $-0.416^{*}$ & 0.039 & 1.381 & -0.302 & 0.092 & 1.381 \\
\hline ROA & - & $-0.008 * *$ & 0.002 & 2.093 & $-0.011 * * *$ & 0 & 2.093 & $-0.007 * *$ & 0.002 & 1.96 & $-0.010 * * *$ & 0.000 & 1.96 \\
\hline LOSS & + & -0.083 & 0.281 & 2.053 & -0.042 & 0.549 & 2.053 & -0.043 & 0.568 & 1.929 & 0.029 & 0.666 & 1.929 \\
\hline LQD & - & $-0.082 * *$ & 0.002 & 1.477 & $-0.059 * *$ & 0.005 & 1.477 & $-0.062 *$ & 0.015 & 1.453 & -0.031 & 0.125 & 1.453 \\
\hline BIG & + & 0.007 & 0.96 & 1.501 & 0.151 & 0.246 & 1.501 & 0.039 & 0.755 & 1.157 & 0.139 & 0.204 & 1.157 \\
\hline PEAK & + & -0.023 & 0.831 & 1.215 & -0.048 & 0.661 & 1.215 & -0.018 & 0.87 & 1.183 & -0.038 & 0.72 & 1.183 \\
\hline NISSUE & + & -0.100 & 0.053 & 1.082 & -0.015 & 0.765 & 1.082 & $-0.106^{*}$ & 0.012 & 1.085 & -0.024 & 0.572 & 1.085 \\
\hline BTP & - & -0.044 & 0.494 & 1.431 & -0.11 & 0.061 & 1.431 & -0.098 & 0.124 & 1.389 & $-0.165 * *$ & 0.005 & 1.389 \\
\hline XLIST & + & $0.456^{*}$ & 0.043 & 1.167 & $0.473^{* *}$ & 0.008 & 1.167 & 0.325 & 0.111 & 1.166 & $0.381^{*}$ & 0.018 & 1.166 \\
\hline MINDEX & + & $0.571 * *$ & 0.001 & 1.777 & $0.509 * *$ & 0.006 & 1.777 & $0.438 *$ & 0.017 & 1.823 & $0.444^{*}$ & 0.012 & 1.823 \\
\hline Constant & & -0.835 & 0.066 & & -0.725 & 0.118 & & $-1.254 * *$ & 0.008 & & $-1.050 *$ & 0.019 & \\
\hline Year effects & & Incl & ded & & Inclu & & & Inc & led & & Incl & & \\
\hline $\mathrm{N}$ & & & & & 42 & & & & & & & & \\
\hline Adjusted R2 & & & & & 0.8 & & & & & & & & \\
\hline p-value & & & & & 0.0 & & & & & & & & \\
\hline Schwartz BIC & & & & & 65 & & & & & & & & \\
\hline VIF & & & & & 1. & & & & & & & & \\
\hline
\end{tabular}

$* \mathrm{p}<0.05, * * \mathrm{p}<0.01, * * * \mathrm{p}<0.001$ (bivariate tests)

With: AUD_FEE = natural log of audit fee $(\mathrm{kDNK})$; TOT_FEE =natural log of total fee $(\mathrm{kDNK})$; JOINT_HAT = the predicted value of a joint audit estimated by the probit selection model for a joint audit (equation (1)); JOINT $=1$ if the firm is audited by two auditors, 0 otherwise; ASSET = natural log of total assets ( $\mathrm{kDNK}$ ); INVR = sum of inventories and receivables divided by total sales; BUS = natural log of (business segments +1 ); LOSS $=1$ if the firm reports a loss, and 0 otherwise; LEV = the ratio of year-end total debt to total assets; ROA = Return on Assets, LQD = the ratio of current assets to current liabilities; PEAK = 1 if the firm's fiscal year-end is 31 rst of December, and 0 otherwise; BIG $=1$ if the firm uses one of the big 4 auditors, and 0 otherwise; XLIST $=1$ if the firm is cross-listed on a UK or US market, and 0 otherwise; 
$\mathrm{BTP}=$ the ratio of common equity to equity price; NISSUE $=1$ if total shares of outstanding increased by $5 \%$ or total debt increased by $5 \%$, and 0 otherwise. MINDEX $=1$ if the firm is listed on the main index, and 0 otherwise. 
Table 9: Abnormal Accrual models regression

Panel A: Accruals: Sample for 2005-2010

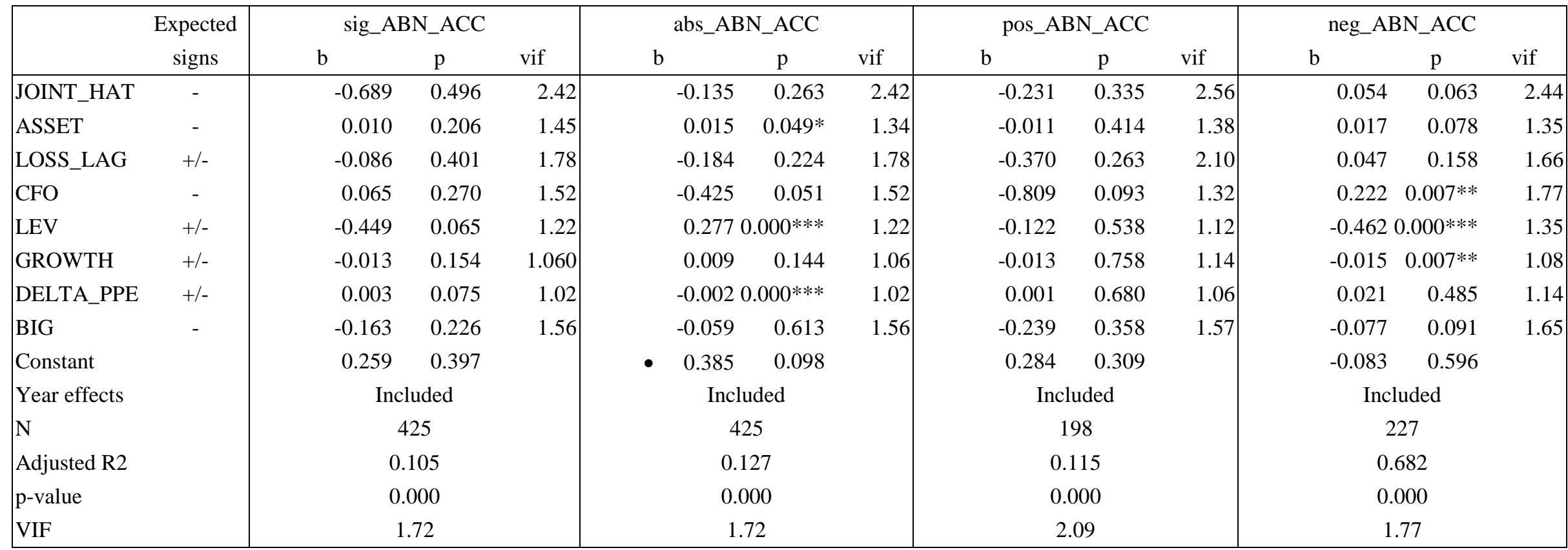

$* \mathrm{p}<0.05, * * \mathrm{p}<0.01, * * * \mathrm{p}<0.001$ (bivariate tests)

With: sig_ABN_ACC $=$ Signed abnormal accruals scaled by lagged assets calculated via linear model adopted from DeFond and Park $(2001)$; abs_ABN_ACC $=$ Absolute abnormal accruals scaled by lagged assets calculated via linear model adopted from DeFond and Park (2001); pos_ABN_ACC = Positive abnormal accruals scaled by lagged assets calculated via linear model adopted from DeFond and Park (2001); neg_ABN_ACC = negative abnormal accruals scaled by lagged assets calculated via linear model adopted from DeFond and Park (2001); JOINT HAT = the predicted value of a joint audit estimated by the probit selection model for a joint audit (equation (1)); ASSET $=$ natural log of total assets in thousands of DNK; LOSS_LAG $=1$ if the firm reports a loss in year t-1, and 0 otherwise; CFO $=$ operating cash flow scaled by total assets; LEV = the ratio of year-end total debt to total assets; GROWTH = sales growth rate; difference between sales in year $\mathrm{t}$ and sales in year $\mathrm{t}-1$ scaled by sales in year t1; DELTA_PPE = growth rate of property plant and equipment $(\mathrm{PPE})$; difference between PPE in year $\mathrm{t}$ and in year $\mathrm{t}-1$ scaled by PPE in year $\mathrm{t}-1$; BIG $=1$ if the firm uses one of the big 4 auditors, and 0 otherwise. 
Panel B: Accruals: Sample for 2002-2010

\begin{tabular}{|c|c|c|c|c|c|c|c|c|c|c|c|c|c|}
\hline & \multirow{2}{*}{$\begin{array}{c}\text { Expected } \\
\text { signs }\end{array}$} & \multicolumn{3}{|c|}{ sig_ABN_ACC } & \multicolumn{3}{|c|}{ abs_ABN_ACC } & \multicolumn{3}{|c|}{ pos_ABN_ACC } & \multicolumn{3}{|c|}{ neg_ABN_ACC } \\
\hline & & $\mathrm{b}$ & $\mathrm{p}$ & vif & $\mathrm{b}$ & $\mathrm{p}$ & vif & $\mathrm{b}$ & $\mathrm{p}$ & vif & $\mathrm{b}$ & $\mathrm{p}$ & vif \\
\hline JOINT & - & -0.027 & 0.534 & 2.78 & -0.033 & 0.449 & 2.78 & -0.052 & 0.479 & 2.79 & -0.008 & 0.733 & 2.80 \\
\hline ASSET & - & 0.009 & 0.198 & 1.27 & -0.018 & $0.020 *$ & 1.27 & -0.017 & - $\quad 0.271$ & 1.31 & 0.020 & $0.011^{*}$ & 1.28 \\
\hline LOSS_LAG & $+/-$ & -0.026 & 0.392 & 1.35 & -0.089 & 0.220 & 1.35 & -0.129 & 0.244 & 1.42 & 0.027 & 0.303 & 1.36 \\
\hline $\mathrm{CFO}$ & - & 0.053 & 0.301 & 1.34 & -0.344 & 0.094 & 1.45 & -0.415 & 0.120 & 1.27 & 0.212 & $0.019^{*}$ & 1.67 \\
\hline LEV & $+/-$ & -0.384 & 0.078 & 1.18 & 0.278 & $0.005 * *$ & 1.18 & -0.120 & 0.432 & 1.10 & -0.441 & $0.001 * *$ & 1.29 \\
\hline GROWTH & $+/-$ & -0.015 & 0.185 & 1.05 & 0.011 & 0.265 & 1.05 & -0.001 & 0.970 & 1.11 & -0.018 & 0.091 & 1.07 \\
\hline DELTA_PPE & $+/-$ & 0.003 & $0.100 *$ & 1.02 & -0.002 & $0.000 * *$ & 1.02 & 0.001 & 0.738 & 1.05 & 0.019 & 0.155 & 1.06 \\
\hline BIG & - & -0.199 & 0.291 & 1.11 & -0.154 & 0.401 & 1.11 & -0.382 & 0.331 & 1.17 & -0.028 & 0.477 & 1.10 \\
\hline Constant & & 0.197 & 0.493 & & 0.469 & 0.070 & & 0.807 & 0.262 & & -0.243 & $0.027 *$ & \\
\hline Year effects & & Inc & uded & & Incl & uded & & & ded & & Incl & uded & \\
\hline $\mathrm{N}$ & & & 82 & & 58 & 82 & & & & & & 06 & \\
\hline Adjusted R2 & & & 88 & & 0.1 & 104 & & & & & & 501 & \\
\hline $\mathrm{p}$-value & & & 00 & & 0.0 & 00 & & & & & & 00 & \\
\hline VIF & & & 79 & & 1. & 79 & & & & & & 91 & \\
\hline
\end{tabular}

$* \mathrm{p}<0.05, * * \mathrm{p}<0.01, * * * \mathrm{p}<0.001$ (bivariate tests)

With: sig_ABN_ACC $=$ Signed abnormal accruals scaled by lagged assets calculated via linear model adopted from DeFond and Park (2001); abs_ABN_ACC = Absolute abnormal accruals scaled by lagged assets calculated via linear model adopted from DeFond and Park (2001); pos_ABN_ACC $=$ Positive abnormal accruals scaled by lagged assets calculated via linear model adopted from DeFond and Park (2001); neg_ABN_ACC = negative abnormal accruals scaled by lagged assets calculated via linear model adopted from DeFond and Park (2001); JOINT = 1 if the firm is audited by two auditors, 0 otherwise; ASSET = natural log of total assets in thousands of DNK; LOSS_LAG $=1$ if the firm reports a loss in year t-1, and 0 otherwise; CFO = operating cash flow scaled by total assets; LEV $=$ the ratio of year-end total debt to total assets; GROWTH = sales growth rate; difference between sales in year $\mathrm{t}$ and sales in year t-1 scaled by sales in year t-1; DELTA_PPE = growth rate of property plant and equipment (PPE); difference between PPE in year $t$ and in year $\mathrm{t}-1$ scaled by PPE in year $\mathrm{t}-1$; BIG $=1$ if the firm uses one of the big 4 auditors, and 0 otherwise. 
Table 10: Comparison France and Germany based on several indices

\begin{tabular}{lll}
\hline & France & Germany \\
\hline Code Law/ Common Law country & Code law & Code law \\
Revised Anti-director Right Index (La Porta et al. 1998) & 3.5 & 3.5 \\
Anti-self Trading Index (Djankov et al. 2008) & 0.38 & 0.28 \\
Doing Business Index" (World Bank) & 5,3 & 5 \\
Expropriation risk (La Porta et al. 1998) & 9,65 & 9,9 \\
Auditor's liability index (Wingate 1997) & 6,22 & 6,22 \\
\hline
\end{tabular}


Table 11: Audit fees models Descriptive statistics

Panel A: Descriptive statistics

\begin{tabular}{|c|c|c|c|c|c|c|c|}
\hline & & $\mathrm{N}$ & mean & $\mathrm{sd}$ & $\min$ & p50 & $\max$ \\
\hline \multirow{18}{*}{ FRA } & Audit fees (k€) & 368 & 2417.7 & 4913.2 & 14.0 & 565.0 & 42600.0 \\
\hline & AUD_FEE & 368 & 6.5 & 1.6 & 2.6 & 6.3 & 10.7 \\
\hline & Non audit fees $(\mathrm{k} €)$ & 368 & 178.3 & 526.4 & 0.0 & 0.5 & 6200.0 \\
\hline & Total fees $(\mathrm{k} €)$ & 368 & 6.6 & 1.6 & 2.6 & 6.3 & 10.7 \\
\hline & TOT_FEE & 368 & 2596.0 & 5143.5 & 14.0 & 570.5 & 44000.0 \\
\hline & ASSET & 368 & 13.337 & 2.142 & 8.814 & 13.234 & 18.161 \\
\hline & INVR & 368 & 0.403 & 0.180 & 0.069 & 0.390 & 0.853 \\
\hline & BUS & 368 & 1.458 & 0.462 & 0.693 & 1.609 & 2.197 \\
\hline & LEV & 368 & 0.219 & 0.151 & 0.000 & 0.198 & 0.593 \\
\hline & ROA & 368 & 5.681 & 5.194 & -9.514 & 5.208 & 23.378 \\
\hline & LOSS & 368 & 0.106 & 0.308 & 0.000 & 0.000 & 1.000 \\
\hline & LQD & 368 & 1.589 & 0.807 & 0.556 & 1.372 & 5.721 \\
\hline & BIG & 368 & 0.750 & 0.434 & 0.000 & 1.000 & 1.000 \\
\hline & PEAK & 368 & 0.774 & 0.419 & 0.000 & 1.000 & 1.000 \\
\hline & NISSUE & 368 & 0.516 & 0.500 & 0.000 & 1.000 & 1.000 \\
\hline & BTP & 368 & 0.863 & 0.760 & 0.085 & 0.619 & 4.570 \\
\hline & CROSSLIST & 368 & 0.190 & 0.393 & 0.000 & 0.000 & 1.000 \\
\hline & MINDEX & 368 & 0.120 & 0.325 & 0.000 & 0.000 & 1.000 \\
\hline \multirow{18}{*}{ GER } & Audit fees $(\mathrm{k} €)$ & 368 & 1300.8 & 3257.2 & 18.0 & 329.0 & 30000.0 \\
\hline & AUD_FEE & 368 & 6.0 & 1.3 & 2.9 & 5.8 & 10.3 \\
\hline & Non audit fees $(\mathrm{k} €)$ & 368 & 610.5 & 2147.0 & 0.0 & 94.0 & 34000.0 \\
\hline & Total fees $(\mathrm{k} €)$ & 368 & 6.3 & 1.4 & 3.1 & 6.1 & 11.1 \\
\hline & TOT_FEE & 368 & 1911.3 & 5031.3 & 23.0 & 445.5 & 64000.0 \\
\hline & ASSET & 368 & 13.291 & 2.074 & 9.484 & 13.048 & 18.335 \\
\hline & INVR & 368 & 0.383 & 0.171 & 0.033 & 0.383 & 0.780 \\
\hline & BUS & 368 & 1.525 & 0.418 & 0.693 & 1.386 & 2.197 \\
\hline & LEV & 368 & 0.235 & 0.174 & 0.000 & 0.222 & 0.690 \\
\hline & ROA & 368 & 4.700 & 7.493 & -25.966 & 5.273 & 25.217 \\
\hline & LOSS & 368 & 0.182 & 0.386 & 0.000 & 0.000 & 1.000 \\
\hline & LQD & 368 & 1.726 & 1.049 & 0.388 & 1.498 & 6.416 \\
\hline & BIG & 368 & 0.726 & 0.447 & 0.000 & 1.000 & 1.000 \\
\hline & PEAK & 368 & 0.861 & 0.346 & 0.000 & 1.000 & 1.000 \\
\hline & NISSUE & 368 & 0.497 & 0.501 & 0.000 & 0.000 & 1.000 \\
\hline & BTP & 368 & 0.746 & 0.519 & 0.038 & 0.612 & 2.523 \\
\hline & XLIST & 368 & 0.590 & 0.493 & 0.000 & 1.000 & 1.000 \\
\hline & MINDEX & 368 & 0.092 & 0.290 & 0.000 & 0.000 & 1.000 \\
\hline
\end{tabular}

With: AUD_FEE $=$ natural log of audit fee (in k€); TOT_FEE =natural log of total fee (in k€); ASSET = natural log of total assets ((in k€); INVR = sum of inventories and receivables divided by total sales; BUS = natural log of (business segments +1$)$; LOSS $=1$ if the firm reports a loss, and 0 otherwise; LEV = the ratio of year-end total debt to total assets; ROA = Return on Assets, LQD = the ratio of current assets to current liabilities; PEAK = 1 if the firm's fiscal year-end is 31 rst of December, and 0 otherwise; BIG $=1$ if the firm uses one of the big 4 auditors, and 0 otherwise; XLIST $=1$ if the firm is cross-listed on a UK or US market, and 0 otherwise; BTP $=$ the ratio of common equity to 
equity price; NISSUE $=1$ if total shares of outstanding increased by $5 \%$ or total debt increased by $5 \%$, and 0 otherwise. MINDEX $=1$ if the firm is listed on the main index, and 0 otherwise.

Panel B: Fees and joint audit

\begin{tabular}{|c|c|c|c|c|c|c|c|c|c|c|}
\hline & \multicolumn{4}{|c|}{$\%$ audit fees/sales } & \multicolumn{3}{|c|}{$\%$ non audit fees/sales } & \multicolumn{3}{|c|}{$\%$ total fees/sales } \\
\hline & $\mathrm{N}$ & mean & $\mathrm{t}$ & p-value & mean & $\mathrm{t}$ & $\mathrm{p}$-value & mean & $\mathrm{t}$ & $\mathrm{p}$-value \\
\hline FRA: joint & 368 & $0.17 \%$ & \multirow{2}{*}{$5.926 * * *$} & \multirow{2}{*}{0.000} & $0.01 \%$ & \multirow{2}{*}{$-7.322 * * *$} & \multirow{2}{*}{0.000} & $0.18 \%$ & \multirow{2}{*}{1.860} & \multirow{2}{*}{0.063} \\
\hline GER: single & 368 & $0.10 \%$ & & & $0.05 \%$ & & & $0.15 \%$ & & \\
\hline Total & 736 & $0.14 \%$ & & & $0.03 \%$ & & & $0.15 \%$ & & \\
\hline
\end{tabular}

With: $* \mathrm{p}<0.05, * * \mathrm{p}<0.01, * * * \mathrm{p}<0.001$ (bivariate tests) 
Table 12: Accruals Models Descriptive Statistics: control variables

Panel A: Descriptive statistics

\begin{tabular}{|c|c|c|c|c|c|c|c|c|}
\hline & $\mathrm{N}$ & & mean & $\mathrm{sd}$ & $\min$ & $\mathrm{p} 50$ & & $\max$ \\
\hline \multirow{11}{*}{ FRA } & sig_ABN_ACC & 368 & 0.1551 & 0.3438 & -0.2587 & & 0.0531 & 2.8694 \\
\hline & abs_ABN_ACC & 368 & 0.1687 & 0.3373 & 0.0001 & & 0.0600 & 2.8694 \\
\hline & pos_ABN_ACC & 297 & 0.2006 & 0.3679 & 0.0001 & & 0.0723 & 2.8694 \\
\hline & neg_ABN_ACC & 71 & -0.0352 & 0.0431 & -0.2587 & & -0.0231 & -0.0001 \\
\hline & ASSET & - 368 & 13.337 & 2.142 & 8.814 & & 13.234 & 18.161 \\
\hline & LOSS_LAG & 368 & 0.082 & 0.274 & 0.000 & & 0.000 & 1.000 \\
\hline & $\mathrm{CFO}$ & 368 & 0.086 & 0.072 & -0.202 & & 0.078 & 0.406 \\
\hline & LEV & 368 & 0.219 & 0.151 & 0.000 & & 0.198 & 0.593 \\
\hline & GROWTH & 368 & 0.073 & 0.221 & -0.833 & & 0.054 & 1.732 \\
\hline & DELTA_PPE & 368 & 0.097 & 0.291 & -0.819 & & 0.056 & 4.207 \\
\hline & BIG & 368 & 0.750 & 0.434 & 0.000 & & 1.000 & 1.000 \\
\hline \multirow{11}{*}{ GER } & sig_ABN_ACC & 368 & 0.1375 & 0.2870 & -0.6899 & & 0.0520 & 2.2563 \\
\hline & abs_ABN_ACC & 368 & 0.1657 & 0.2716 & 0.0003 & & 0.0667 & 2.2563 \\
\hline & pos_ABN_ACC & 275 & 0.2029 & 0.3012 & 0.0003 & & 0.0917 & 2.2563 \\
\hline & neg_ABN_ACC & - 93 & -0.0557 & 0.0885 & -0.6899 & & -0.0305 & -0.0004 \\
\hline & ASSET & 368 & 13.291 & 2.074 & 9.484 & & 13.048 & 18.335 \\
\hline & LOSS_LAG & 368 & 0.101 & 0.301 & 0.000 & 0.000 & & 1.000 \\
\hline & $\mathrm{CFO}$ & 368 & 0.074 & 0.081 & -0.366 & & 0.078 & 0.346 \\
\hline & LEV & 368 & 0.235 & 0.174 & 0.000 & & 0.222 & 0.690 \\
\hline & GROWTH & 368 & 0.056 & 0.204 & -0.834 & & 0.052 & 0.903 \\
\hline & DELTA_PPE & 368 & 0.114 & 0.892 & -0.745 & & 0.046 & 16.560 \\
\hline & BIG & 368 & 0.726 & 0.447 & 0.000 & & 1.000 & 1.000 \\
\hline
\end{tabular}

With: sig_ABN_ACC $=$ Signed abnormal accruals scaled by lagged assets calculated via linear model adopted from DeFond and Park (2001); abs_ABN_ACC = Absolute abnormal accruals scaled by lagged assets calculated via linear model adopted from DeFond and Park (2001); pos_ABN_ACC = Positive abnormal accruals scaled by lagged assets calculated via linear model adopted from DeFond and Park (2001); neg_ABN_ACC = negative abnormal accruals scaled by lagged assets calculated via linear model adopted from DeFond and Park (2001); ASSET = natural log of total assets in thousands of EURO; LOSS_LAG $=1$ if the firm reports a loss in year t 1 , and 0 otherwise; CFO = operating cash flow scaled by total assets; LEV = the ratio of year-end total debt to total assets; GROWTH = sales growth rate; difference between sales in year $\mathrm{t}$ and sales in year $\mathrm{t}-1$ scaled by sales in year $\mathrm{t}-1$; DELTA_PPE $=$ growth rate of property plant and equipment (PPE); difference between PPE in year $\mathrm{t}$ and in year $\mathrm{t}-1$ scaled by PPE in year $\mathrm{t}-1$; $\mathrm{BIG}=1$ if the firm uses one of the big 4 auditors, and 0 otherwise. 
Panel B: Accruals and joint audit

\begin{tabular}{|c|c|c|c|c|c|c|c|c|c|c|c|c|c|c|}
\hline \multirow[b]{2}{*}{ DNK } & & \multirow[b]{2}{*}{$\mathrm{N}$} & \multicolumn{3}{|c|}{ sig_ABN_ACC } & \multicolumn{3}{|c|}{ abs_ABN_ACC } & \multicolumn{3}{|c|}{ pos_ABN_ACC } & \multicolumn{3}{|c|}{ neg_ABN_ACC } \\
\hline & & & mean & $\mathrm{t}$ & $\begin{array}{l}\mathrm{p}- \\
\text { value }\end{array}$ & mean & $\mathrm{t}$ & $\begin{array}{l}\mathrm{p}- \\
\text { value }\end{array}$ & mean & $\mathrm{t}$ & $\begin{array}{l}\mathrm{p}- \\
\text { value }\end{array}$ & mean & $\mathrm{t}$ & p-value \\
\hline \multirow{3}{*}{$\begin{array}{l}\mathrm{N}=582 \\
(2002-2010)\end{array}$} & Joint & $\begin{array}{r}368 \\
(297 / 71)\end{array}$ & 0.155 & \multirow{2}{*}{-0.754} & \multirow{2}{*}{0.451} & & \multirow[t]{2}{*}{-0.134} & \multirow{2}{*}{0.894} & 0.201 & \multirow{2}{*}{0.078} & \multirow{2}{*}{0.936} & -0.035 & \multirow{2}{*}{-1.795} & \multirow{2}{*}{0.075} \\
\hline & Single & $\begin{array}{r}368 \\
(275 / 93)\end{array}$ & 0.138 & & & 0.166 & & & 0.203 & & & -0.056 & & \\
\hline & Total & 736 & & & & & & & & & & & & \\
\hline
\end{tabular}

With: * $\mathrm{p}<0.05, * * \mathrm{p}<0.01, * * * \mathrm{p}<0.001$ (bivariate tests) 
Table 13: Audit fees models regressions

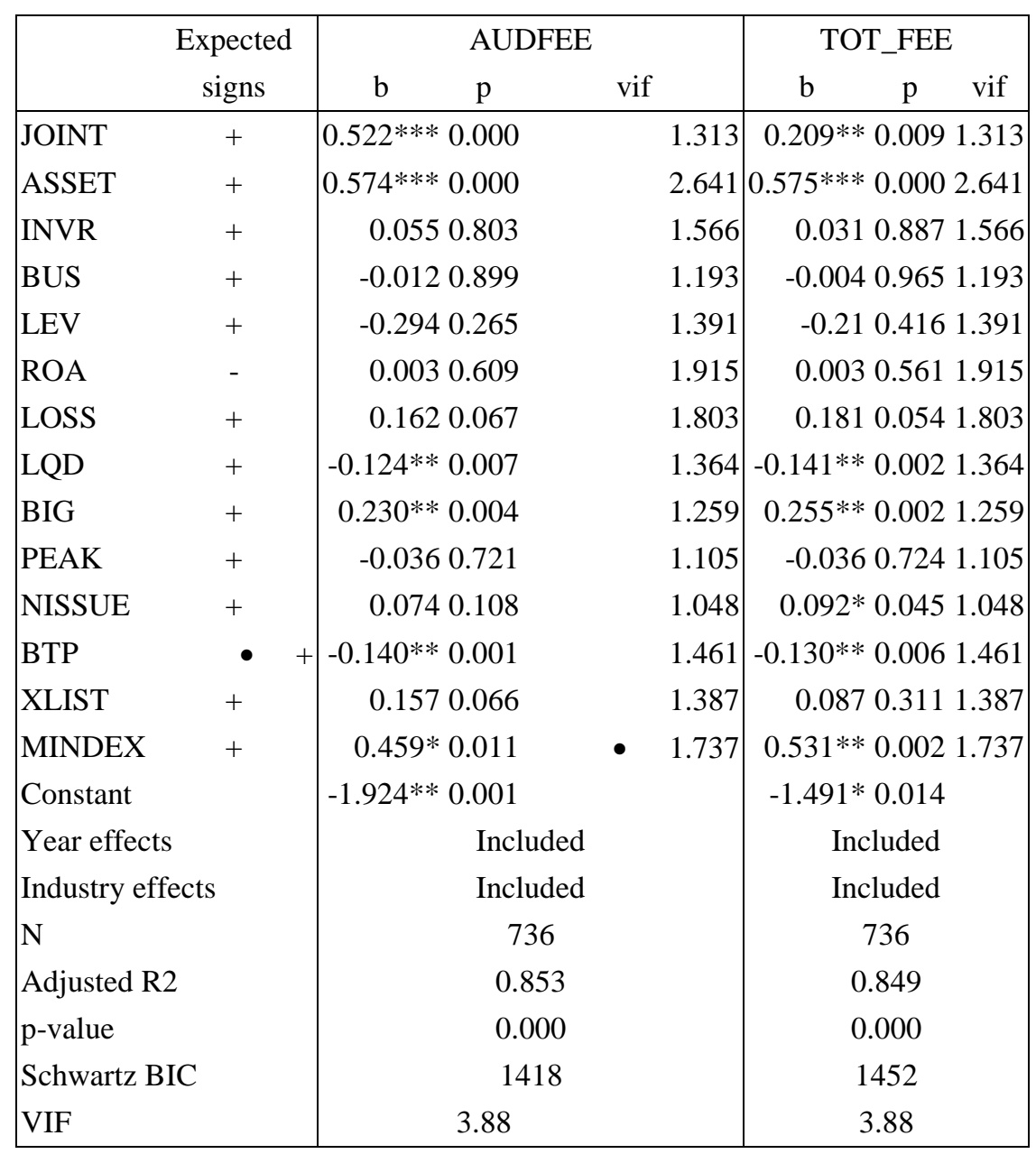

$* \mathrm{p}<0.05, * * \mathrm{p}<0.01, * * * \mathrm{p}<0.001$ (bivariate tests)

With: AUD_FEE = natural log of audit fee in thousands of Euros; TOT_FEE $=$ natural log of total fee in thousands of Euros; JOINT $=1$ if the firm uses at least 2 auditors, and 0 otherwise; ASSET $=$ natural $\log$ of total assets in thousands of Euros; BUS = natural log of (business segments +1 ); LOSS = 1 if the firm reports a loss, and 0 otherwise; LEV = the ratio of year-end total debt to total assets; ROA = Return on Assets, LQD = the ratio of current assets to current liabilities; PEAK = 1 if the firm's fiscal year-end is 31 rst of December, and 0 otherwise; BIG =1 if the firm uses one of the big 4 auditors, and 0 otherwise; XLIST $=1$ if the firm is cross-listed on a UK or US market, and 0 otherwise; BTP = the ratio of common equity to equity price; NISSUE $=1$ if total shares of outstanding increased by $5 \%$ or total debt increased by $5 \%$, and 0 otherwise. MINDEX $=1$ if the firm is listed on the main index, and 0 otherwise. 
Table 14: Abnormal Accrual models regression

\begin{tabular}{|c|c|c|c|c|c|c|c|c|c|c|c|c|c|}
\hline \multirow{2}{*}{\multicolumn{2}{|c|}{$\begin{array}{c}\text { Expected } \\
\text { signs }\end{array}$}} & \multicolumn{3}{|c|}{ sig_ABN_ACC } & \multicolumn{3}{|c|}{ - abs_ABN_ACC } & \multicolumn{3}{|c|}{ pos_ABN_ACC } & \multicolumn{3}{|c|}{ neg_ABN_ACC } \\
\hline & & $\mathrm{b}$ & $\mathrm{p}$ & vif & $\mathrm{b}$ & $\mathrm{p}$ & vif & $\mathrm{b}$ & $\mathrm{p}$ & vif & $\mathrm{b}$ & $\mathrm{p}$ & - vif \\
\hline JOINT & - & 0.022 & 0.406 & 1.01 & 0.005 & 0.848 & 1.01 & 0.022 & 0.514 & 1.02 & 0.021 & $0.031 *$ & 1.05 \\
\hline ASSET & - & -0.0840 & $000 * * *$ & 1.26 & -0.078 & $000 * * *$ & 1.26 & -0.100 & $.000 * * *$ & 1.22 & 0.001 & 0.695 & 1.36 \\
\hline LOSS_LAG & $+/-$ & 0.028 & 0.437 & 1.08 & 0.044 & 0.243 & 1.08 & 0.031 & 0.473 & 1.09 & -0.024 & 0.181 & 1.16 \\
\hline $\mathrm{CFO}$ & - & -0.596 & $0.015^{*}$ & 1.10 & -0.323 & 0.207 & 1.10 & -0.564 & $0.070^{*}$ & 1.12 & -0.366 & $0.013 *$ & 1.16 \\
\hline LEV & $+/-$ & $-0.263 c$ & $000 * * *$ & 1.10 & -0.205 & $0.015^{*}$ & 1.10 & -0.310 & $0.001 * *$ & 1.11 & -0.104 & 0.179 & 1.10 \\
\hline GROWTH & $+/-$ & 0.130 & $0.020 *$ & 1.25 & 0.131 & $0.019 *$ & 1.25 & 0.155 & $0.018^{*}$ & 1.17 & 0.040 & 0.556 & 2.84 \\
\hline DELTA_PPE & $+/-$ & -0.006 & 0.423 & 1.10 & 0.001 & 0.944 & 1.10 & -0.001 & 0.928 & 1.08 & -0.073 & $0.010 *$ & 2.16 \\
\hline $\mathrm{BIG}$ & - & 0.036 & 0.313 & 1.20 & 0.036 & 0.317 & 1.20 & 0.042 & 0.276 & 1.16 & -0.017 & 0.415 & - $\quad 1.27$ \\
\hline Constant & & 1.3720 & $000 * * *$ & & 1.279 & $000 * * *$ & & 1.544 & $.000 * * *$ & & 0.017 & 0.776 & \\
\hline Year effects & & Inc & ided & & Incl & ded & & Inc & uded & & & Included & \\
\hline $\mathrm{N}$ & & & 36 & & & & & & 72 & & & 164 & \\
\hline Adjusted R2 & & & 10 & & & & & & 407 & & & 0.682 & \\
\hline p-value & & & 00 & & & & & & 000 & & & 0.000 & \\
\hline VIF & & & 33 & & & & & & 30 & & & 1.77 & \\
\hline
\end{tabular}

$* \mathrm{p}<0.05, * * \mathrm{p}<0.01, * * * \mathrm{p}<0.001$ (bivariate tests)

With: sig_ABN_ACC $=$ Signed abnormal accruals scaled by lagged assets calculated via linear model adopted from DeFond and Park $(2001)$; abs_ABN_ACC $=$ Absolute abnormal accruals scaled by lagged assets calculated via linear model adopted from DeFond and Park (2001) (calculation see $\S 3.2$ ); JOINT $=1$ if the firm uses at least 2 auditors, and 0 otherwise; ASSET $=$ natural $\log$ of total assets in thousands of Euros; LOSS_LAG $=1$ if the firm reports a loss in year t or year t-1, and 0 otherwise; CFO = operating cash flow scaled by total assets; LEV = the ratio of year-end total debt to total assets; GROWTH = sales growth rate; difference between sales in year $t$ and sales in year t-1 scaled by sales in year t-1; DELTA_PPE = growth rate of property plant and equipment (PPE); difference between PPE in year $\mathrm{t}$ and in year t-1 scaled by PPE in year $\mathrm{t}-1 ; \mathrm{BIG}=1$ if the firm uses one of the big 4 auditors, and 0 otherwise. 